\title{
Hydroalcoholic Extract from Inflorescences of Achyrocline satureioides (Compositae) Ameliorates Dextran Sulphate Sodium-Induced Colitis in Mice by Attenuation in the Production of Inflammatory Cytokines and Oxidative Mediators
}

\author{
Luisa Mota da Silva, Jaime Antonio Machado Farias, \\ Thaise Boeing, Lincon Bordignon Somensi, Ana Paula Beber, Benhur Judah Cury, \\ José Roberto Santin, and Sérgio Faloni de Andrade \\ Programa de Pós-Graduação em Ciências Farmacêuticas (PPGCF), Núcleo de Investigacões Químico-Farmacêuticas (NIQFAR), \\ Universidade do Vale do Itajaí (UNIVALI), Rua Uruguai, 458, Centro, 88302-202 Itajaí, SC, Brazil
}

Correspondence should be addressed to Sérgio Faloni de Andrade; faloni@univali.br

Received 15 June 2016; Accepted 21 September 2016

Academic Editor: Roberto K. N. Cuman

Copyright (C) 2016 Luisa Mota da Silva et al. This is an open access article distributed under the Creative Commons Attribution License, which permits unrestricted use, distribution, and reproduction in any medium, provided the original work is properly cited.

\begin{abstract}
Achyrocline satureioides is a South American herb used to treat inflammatory and gastrointestinal diseases. This study evaluated intestinal anti-inflammatory effects of the hydroalcoholic extract of inflorescences of satureioides (HEAS) in dextran sulfate sodium (DSS) induced colitis in mice. Mice were orally treated with vehicle, 5 -aminosalicylic acid (100 mg/kg), or HEAS (1-100 mg/kg). Clinical signs of colitis and colonic histopathological parameters were evaluated, along with the determination of levels of reduced glutathione and lipid hydroperoxide (LOOH), the superoxide dismutase (SOD), and myeloperoxidase (MPO) activity in colon. The colonic content of cytokines (TNF, IL-4, IL-6, and IL-10) was measured. Additionally, the effects of the extract on nitric oxide (NO) release by lipopolysaccharide (LPS) stimulated macrophages and diphenylpicrylhydrazyl levels were determined. Mucin levels and SOD activity, as well as the LOOH, MPO, TNF, and IL-6 accumulation in colon tissues, were normalized by the HEAS administration. In addition, the extract elicited an increase in IL-4 and IL-10 levels in colon. NO release by macrophages was inhibited by HEAS and its scavenger activity was confirmed. Together these results suggest that preparations obtained from inflorescences from A. satureioides could be used in treatment for IBD. Besides, this work corroborates the popular use of $A$. satureioides in inflammatory disorders.
\end{abstract}

\section{Introduction}

Ulcerative colitis (UC) is chronic inflammatory bowel disease (IBD) characterized by diffuse inflammation of the rectal and colonic mucosa [1]. The incidence and prevalence of this chronic condition have increased worldwide but diverge widely among geographic regions [2]. The precise etiology of ulcerative colitis is unknown, but it is thought that mucosal inflammation is the result of an abnormal colonic immune response and interactions between genetics, colonic gut flora, and environmental factors [3]. Patients with inflammation in the intestinal mucosa complain of symptoms such as bloody diarrhea, abdominal pain, urgency, and tenesmus [4].

The conventional treatment of UC includes the use of anti-inflammatory drugs (aminosalicylates or corticosteroids), immunosuppressant, antibiotics, and biologic agents [5]. This therapy is carried out by a step-up strategy in accordance with severity of symptoms aiming to induce and maintain the disease remission and improve the quality of life [4]. In addition, the therapy also decreases the risk of complications, such as developing colorectal cancer [6]. However, drug refractoriness, intolerance, major adverse 
events, and poor treatment responses are related to the current therapy of UC [7]. In this scenario, treatment modalities that effectively attenuate the bowel inflammation due to UC with fewer adverse effects are need. The use of herbal therapy in inflammatory bowel diseases (IBD) is increasing worldwide, and it is clear that alternative or complementary medicine is an interesting source for the discovery of new, more effective, and safe drug.

Achyrocline satureioides (Lam.) DC (Compositae) is a medium-sized South American indigenous herb distributed in Europe and Africa popularly known as "Marcela" or "Macela" [8]. Infusions of the inflorescences from this species are used in Brazilian folk medicine to treat central nervous system diseases, respiratory diseases, inflammatory disorders, and gastrointestinal system diseases [9]. More particularly, there are several reports indicating that tea prepared mainly by communities of South Brazil, from the inflorescences of $A$. satureioides, leads to the relief of the symptoms of gastric ulcers $[10,11]$ and inflammatory diseases of the gastrointestinal tract, such as Crohn's disease [11, 12]. In line with its traditional use, the anti-inflammatory activity of extracts from $A$. satureioides has been confirmed in different studies $[11,13,14]$. Santin et al. [15] previously confirmed the antiulcer gastric potential of this plant and its antispasmodic effect in gastrointestinal smooth muscle preparation has also been described [13]. Moreover, no signs of toxicity were detected after the administration of the hydroalcoholic extract from inflorescences of $A$. satureioides at a dose of $2000 \mathrm{mg} / \mathrm{kg}$ in female rats [15]. However, despite these findings and popular usage to treat IBD, no reports are available about the intestinal anti-inflammatory effects $A$. satureioides preparations. Therefore, the present study has been designed to examine the intestinal anti-inflammatory effects of the hydroalcoholic extract of inflorescences of $A$. satureioides (HEAS), which has already been chemically characterized being the major components identified as quercetin and luteolin [14], in dextran sulfate sodium (DSS) induced colitis in mice.

\section{Material and Methods}

2.1. Chemicals. The following substances were used: 2,2diphenyl-1-picrylhydrazyl, 5,5'-dithiobis (2-nitrobenzoic acid), bovine serum albumin, glutathione, butylated hydroxytoluene, Griess reagent, MTT, pyrogallol, xylenol orange (all from Sigma, St. Louis, USA), absolute ethanol, acetic acid, ascorbic acid, ferrous ammonium sulfate, hydrochloric acid, formaldehyde, hydrogen peroxide, methanol, sodium acetate, trichloroacetic acid (Vetec, Rio de Janeiro, RJ, Brazil), sulfuric acid, dimethyl sulfoxide and N,Ndimethylformamide (DMSO, Synth, Diadema, SP, Brazil), Dulbecco's Modified Eagle Medium (DMEM, Vitrocell, Campinas, SP, Brazil), fetal bovine serum (FBS, Gibco), and dextran sulfate sodium (Alfa Aesar, Heysham, Lancashire, $\mathrm{UK})$.

2.2. Plant Material, Preparation of the Extract, and Phytochemical Identification. Inflorescences of $A$. satureioides were collected in Fraiburgo, Santa Catarina, Brazil. A voucher specimen is deposited at the herbarium of the Universidade Estadual de Maringá (UEM) under the number HUEM23568. Professor Oscar Iza authenticated the sample.

The extraction procedures had already been published by Barioni et al. [14]. Air-dried inflorescences $(2 \mathrm{~kg}$ ) were cut into small pieces and macerated with $70 \%(\mathrm{v} / \mathrm{v})$ aqueous ethanol $(10 \mathrm{~L})$ at room temperature for 7 days. The hydroalcoholic extract of inflorescences of $A$. satureioides (HEAS) was obtained by filtration of the macerated material and solvent evaporation under reduced pressure, yielding $192.6 \mathrm{~g}$ (9.6\%) of hydroalcoholic extract.

The phytochemical composition of HEAS was also previously described by Barioni et al. [14], and the flavonoids luteolin and quercetin were identified as the major constituents.

Aiming to establish standardization, the total phenolic and flavonoid content were quantified in HEAS. The total phenolic content was verified by Folin-Ciocalteu reagent according to the method described by Arnous et al. [16]: HEAS $(50,100,150$, and $200 \mu \mathrm{g} / \mathrm{mL})$ was mixed with $0.5 \mathrm{~mL}$ of distilled water and $2.5 \mathrm{~mL}$ of Folin-Ciocalteu reagent $(1: 10$ dilution) and $2.0 \mathrm{~mL}$ of sodium carbonate $(7.5 \% \mathrm{w} / \mathrm{v})$ were added in the tubes. Further, the tubes were incubated at $45^{\circ} \mathrm{C}$ for $15 \mathrm{~min}$. The absorbance was determined at $760 \mathrm{~nm}$ in spectrophotometer. The total polyphenol concentration was calculated from a calibration curve, using tannic acid as a standard. Results were expressed as tannic acid equivalents (TAE) in $\mu \mathrm{g}$.

The flavonoid content was estimated by the $\mathrm{AlCl}_{3}$ method [17]: $1 \mathrm{~mL}$ of methanolic extract solution $(50-200 \mu \mathrm{g} / \mathrm{mL})$ was added to equal volume of $2 \%$ methanolic $\mathrm{AlCl}_{3}, 6 \mathrm{H}_{2} \mathrm{O}$. The absorbance was measured $10 \mathrm{~min}$ later at $430 \mathrm{~nm}$. The results were expressed in mg quercetin/100 g dry extract by comparison with standard quercetin treated in the same conditions.

2.3. Animals. Swiss female mice (25-30 g) and female Wistar rats $(180-200 \mathrm{~g})$ were purchased from animal house of the Universidade do Vale do Itajai (UNIVALI), Itajaí, SC, Brazil. All mice were housed six per cage in the animal room at $22 \pm$ $2{ }^{\circ} \mathrm{C}$ under a $12 \mathrm{~h}$ light $/ 12 \mathrm{~h}$ dark cycle and with access to food and water ad libitum. All experimental animal procedures were approved by the Institutional Ethics Committee of the UNIVALI under approval certificate number 035/15 and were carried out in accordance with the international standards and the ethical guidelines on animal welfare.

2.4. Dosage Fixation. The doses of HEAS used in this study were 1,10 , and $100 \mathrm{mg} / \mathrm{kg}$ administered by oral route. This range of doses was based on data previously published by Barioni et al. [14] and Santin et al. [15], which addressed the gastroprotective and the anti-inflammatory effects of HEAS in doses established in folk medicine.

2.5. Induction of Colitis. Mice were randomly divided into three groups $(n=10)$. Colonic inflammation was induced by addition of 3\% (w/v) DSS (MW: 40,000) in drinking water ad libitum for 5 days, as described by Chassaing et al. [18]. Noncolitic group did not receive DSS in drinking 


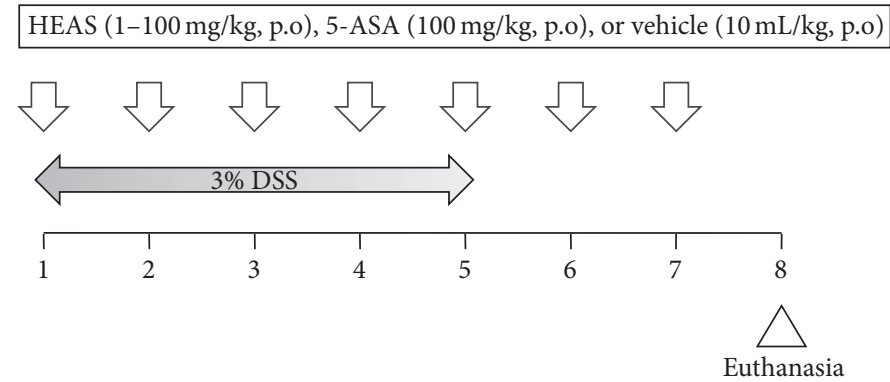

FIGURE 1: Experimental protocol. The animals were treated with vehicle or HEAS (100 mg/kg, po) daily for seven days. Simultaneously, the animals received $3 \%$ DSS from 1st to 5 th day of treatment.

TABLE 1: DAI Score.

\begin{tabular}{lccc}
\hline Score & Weight loss & Stool consistency & Rectal bleeding \\
\hline 0 & None & Normal & Normal \\
1 & $1-5 \%$ & - & - \\
2 & $5-10 \%$ & Loose stools & - \\
3 & $10-20 \%$ & - & - \\
4 & $>20 \%$ & Diarrhea & Gross bleeding \\
\hline
\end{tabular}

DAI value is composed by the sum of the scores of weight loss, stool consistency and rectal bleeding. Maximum score: 12 .

water. Control-colitic group was treated once a day, for 7 days, with vehicle (water, $10 \mathrm{~mL} / \mathrm{kg}$ ). HEAS-treated colitic group received the extract $(1,10$, and $100 \mathrm{mg} / \mathrm{kg}$, po) once a day for 7 days. The positive control agent used in this experiment was 5-aminosalicylic acid (5-ASA), administered at a dose of $100 \mathrm{mg} / \mathrm{kg}$ (p.o) once a day for 7 days in colitic animals. The treatment with vehicle or extract started simultaneously with the DSS administration and the experimental protocol is showed in Figure 1. Animal body weight, the presence of rectal gross blood, and stool consistency were individually evaluated daily. Each parameter was assigned a score according to the criteria previously proposed $[19,20]$ and used to calculate on average daily the Disease Activity Index (DAI) (Table 1). The animals were euthanized at 8th day after the beginning of treatments, at which the colon was excised, weighed, and measured in length. In addition, representative specimens $(0.5 \mathrm{~cm}$ length) containing all wall layers were taken from the proximal inflamed region and fixed in ALFAC solution (a mixture containing $80 \%$ alcohol, 15\% formaldehyde, and $5 \%$ acetic acid) for the histological studies; equivalent colonic segments were also obtained from the noncolitic group. The remaining colonic tissue was subsequently sectioned in different longitudinal fragments to be used for inflammatory and oxidative parameters measurement. Furthermore, the liver and spleen from colitic and noncolitic mice were excised and weighed. Moreover, feces were collected for occult blood measurement by Mayer method and for intestinal bleeding score calculation [18].

\subsection{Histological Studies}

2.6.1. Histopathological Analysis. Tissue sections of colonic tissue were embedded in paraffin. Full thickness sections
TABLE 2: Variables used in the histological score.

\begin{tabular}{|c|c|c|}
\hline Findigns & Score & Criteria \\
\hline \multirow{4}{*}{$\begin{array}{l}\text { Mucosal } \\
\text { epithelium }\end{array}$} & 0 & No mucosa inflammation \\
\hline & 1 & Loss of $<5 \%$ of the epithelial surface \\
\hline & 2 & Loss of $5-10 \%$ of the epithelial surface \\
\hline & 3 & Loss of $>10 \%$ of the epithelial surface \\
\hline \multirow{4}{*}{$\begin{array}{l}\text { Integrity of } \\
\text { crypts }\end{array}$} & 0 & Intact crypts \\
\hline & 1 & Loss of $<10 \%$ of crypts \\
\hline & 2 & Loss of $10-20 \%$ of crypts \\
\hline & 3 & Loss of $>20 \%$ of crypts \\
\hline \multirow{4}{*}{$\begin{array}{l}\text { Cell infiltrate } \\
\text { and edema }\end{array}$} & 0 & None \\
\hline & 1 & Mild \\
\hline & 2 & Moderate \\
\hline & 3 & Severe \\
\hline \multirow{2}{*}{$\begin{array}{l}\text { Goblet cells } \\
\text { depletion }\end{array}$} & 0 & Absent \\
\hline & 1 & Present \\
\hline
\end{tabular}

Histological score value is composed by the sum of the scores of all variables. Maximum score: 10.

of $5 \mu \mathrm{m}$ were stained with hematoxylin and eosin (HE). After that, the slides were dehydrated, cleared, and mounted between slide and cover slip. The histological damage was evaluated by a pathologist observer, according to the criteria previously described by Utrilla et al. [19] and Camuesco et al. [20], with few modifications, and taking into account the presence of epithelial loss, cell infiltration, edema, and the condition of the crypts and Goblet cells. The colonic tissue was evaluated focusing on the previous features and a score ranging from 0 (healthy tissue) to 3 or 4 (severe damage), depending on the item, was assigned to each one (full details in Table 2). The sum gives the total score for each sample.

2.6.2. Histochemical Analysis. For mucin content analysis, the histologic sections, obtained as described above, were oxidized in $0.5 \%$ periodic acid in water, at room temperature, for $5 \mathrm{~min}$. The tissue was then washed in water, immersed in Schiff's reagent for $20 \mathrm{~min}$, and rinsed in water for $5 \mathrm{~min}$ and then three times in $0.5 \%$ sodium meta-bisulphite before a final wash in water. After that, sections were stained with hematoxylin for $20 \mathrm{~s}$, dehydrated, cleared, and mounted between slide and cover slip. Next, the slides were observed 
in optical microscope and photographed. In addition, the glycoproteins were quantified using the program Image $\mathrm{J}^{\circledR}$ and expressed as pixels/field.

2.7. Preparation of Subcellular Fractions of Tissues. Colon samples from the different experimental groups were homogenized with $200 \mathrm{mM}$ potassium phosphate buffer ( $\mathrm{pH}$ 6.5), and the homogenate was used to measure the reduced glutathione (GSH), lipid hydroperoxide $(\mathrm{LOOH})$, and cytokines levels. After that, the homogenate was centrifuged at $4000 \mathrm{rpm}$ for $20 \mathrm{~min}$ at $4^{\circ} \mathrm{C}$, myeloperoxidase (MPO) activity was measured in the precipitate, and superoxide dismutase (SOD) activity was determined in supernatant.

2.8. Protein Assay. Protein levels were determined by the Bradford method (Bio-Rad, Hercules, CA, USA), using a standard curve of bovine serum albumin $(0.1-0.0125 \mu \mathrm{g} / \mathrm{mL})$ as standard, according to instructions of the manufacturer.

\subsection{Determination of Oxidative Parameters}

2.9.1. Determination of GSH Levels. GSH levels in colon were determined as previously described [21]. Briefly, aliquots of the homogenate prepared as described above were mixed with $12.5 \%$ trichloroacetic acid and centrifuged at $6000 \mathrm{rpm}$, $20 \mathrm{~min}$. The absorbance of supernatant plus TRIS buffer (0.4 M, pH 8.9) and 5,5'-dithiobis 2-nitrobenzoic acid (DTNB, $0.01 \mathrm{M}$ ) was determined spectrophotometrically at $415 \mathrm{~nm}$. The individual values were interpolated in a standard curve of GSH $(1.25-10 \mu \mathrm{g} / \mathrm{mL})$ and expressed as $\mathrm{mg} / \mathrm{g}$ of tissue. All procedures were performed at $4^{\circ} \mathrm{C}$.

2.9.2. Determination of LOOH Content. The levels of $\mathrm{LOOH}$ in colon were determined as previously described by the method of Ferrous Oxidation-Xylenol Orange (FOX2) [22]. In this assay, $100 \mu \mathrm{L}$ of supernatant plus $100 \mu \mathrm{L}$ of methanol P.A. was centrifuged at $13000 \mathrm{rpm}$ for 5 minutes $\left(4^{\circ} \mathrm{C}\right)$. FOX2 reagent ( $4 \mathrm{mM}$ butylated hydroxytoluene $(\mathrm{BHT}), 250 \mathrm{mM}$ $\mathrm{FeSO}_{4}, 25 \mathrm{mM} \mathrm{H} \mathrm{SO}_{4}$, and xylenol orange at $100 \mathrm{mM}$ ) were added to supernatant and incubated, in dark, for $30 \mathrm{~min}$ at room temperature. The absorbance was determined spectrophotometrically at $560 \mathrm{~nm}$, and the concentration of $\mathrm{LOOH}$ content was calculated using molar extinction coefficient $\left(E=43 \mathrm{mM}^{-1} \mathrm{~cm}^{-1}\right)$ and expressed as mmol hydroperoxides/mg of tissue.

2.9.3. Determination of SOD Activity. SOD activity was measured based on its ability to inhibit the pyrogallol autoxidation [23]. Briefly, aliquots of the supernatant were added to buffer solution (200 mM TrisHCl-EDTA, $\mathrm{pH} 8.5$ ), and pyrogallol $(1 \mathrm{mM})$ and then incubated for $20 \mathrm{~min}$ at room temperature. Further, $\mathrm{HCl} 1 \mathrm{~N}$ was added to stop the reaction and then the mixture was centrifuged for $4 \mathrm{~min}$ at $18700 \times \mathrm{g}$. The absorbance of the resulting supernatant was measured at $405 \mathrm{~nm}$. The amount of SOD that inhibited the oxidation of pyrogallol by $50 \%$, relative to the control, was defined as one unit of SOD activity. The SOD activity was expressed as U/mg of protein.
2.9.4. In Vitro 2,2-Diphenyl-1-picrylhydrazyl (DPPH) Scavenging Activity. The DPPH assay has been widely used as a tool to estimate the free radical scavenging activity of antioxidants constituents in plant extracts. The reduction capacity of the DPPH radical was determined by the decrease in absorbance induced by antioxidants according to Blois [24] and Chen et al. [25], with modifications. Different concentrations of HEAS $(1,10,100$, and $1000 \mu \mathrm{g} / \mathrm{mL})$ were mixed with DPPH methanolic solution $(10 \mu \mathrm{g} / \mathrm{mL})$. In this test, ascorbic acid $(50 \mu \mathrm{g} / \mathrm{mL})$ was used as a positive control. The solutions were mixed and incubated for $5 \mathrm{~min}$ at room temperature and the absorbance was read at $517 \mathrm{~nm}$. The individual values were interpolated to a standard curve of DPPH $(0-60 \mu \mathrm{M})$ and expressed as $\mu \mathrm{M}$ de DPPH. All the experiments were performed in triplicate.

\subsection{Determination of Inflammatory Parameters}

2.10.1. Measurement of In Vivo MPO Activity. Colonic and hepatic MPO activity were measured according to the method described by Bradley et al. [26] and modified by De Young et al. [27]. Briefly, precipitate of the homogenate prepared as described above was mixed in $80 \mathrm{mM}$ potassium phosphate buffer ( $\mathrm{pH}$ 5.4) containing $0.5 \%$ hexadecyltrimethylammonium bromide (HTAB) and centrifuged $\left(12000 \mathrm{rpm}\right.$ for $20 \mathrm{~min}$ at $\left.4^{\circ} \mathrm{C}\right)$. MPO activity was determined at $620 \mathrm{~nm}$ in the supernatant in presence of $\mathrm{H}_{2} \mathrm{O}_{2}$ and $3,3^{\prime}, 5,5^{\prime}$-tetramethylbenzidine (TMB). MPO activity was expressed as units of optic density (mO.D.)/mg of protein.

2.10.2. Determinations of Cytokine Levels. Colonic homogenates were used to estimate the TNF- $\alpha$, IL- 6 , IL- 4 , and IL10 levels by enzyme-linked immunosorbent assay (ELISA), using mouse cytokine ELISA kits from BD Biosciences (Franklin Lakes, New Jersey, USA), according to the manufacturer's instructions. The absorbance was measured at 450 and $550 \mathrm{~nm}$ and the results were expressed as $\mathrm{pg} / \mathrm{mL}$.

\subsubsection{Nitric Oxide Determination in Isolated Rat Peritoneal} Macrophage Stimulated with LPS. Untreated Wistar rats were given a volume of $5 \mathrm{~mL}$ intraperitoneal injection of $3 \%$ thioglycollate in PBS. Four days later, mouse peritoneal macrophages were collected through peritoneal lavage with PBS, pelleted, and washed in PBS. Cells were plated at a density of $1 \times 10^{6}$ cells per $\mathrm{mL}$ with Dulbecco's Modified Eagle Medium (DMEM) supplemented with $10 \%$ fetal bovine serum, penicillin $(100 \mathrm{U} / \mathrm{mL})$, and streptomycin $(100 \mathrm{U} / \mathrm{mL})$. Cells were given $2 \mathrm{~h}$ to adhere, after which the medium was changed, and adherent cells were treated with $\operatorname{HEAS}(1,10$, and $100 \mu \mathrm{g} / \mathrm{mL})$ and stimulated with LPS $(1 \mu \mathrm{g} / \mathrm{mL})$ for $24 \mathrm{~h}$ without removing the extract from the culture medium. The supernatant was used for nitric oxide measurement.

Nitric oxide levels were assessed by means of nitrite quantification as described by Grisham et al. [28]. Briefly, $100 \mu \mathrm{L}$ of culture medium was incubated for $15 \mathrm{~min}$ with Griess reagent. Absorbance was read at $540 \mathrm{~nm}$. 
2.11. Cell Viability Assay. Cell viability was determined using the MTT reduction assay. Peritoneal macrophages were seeded in a 96-well plate at density of $10^{5}$ cells/well and treated with different concentrations of HEAS $(1,10$, and $100 \mu \mathrm{g} / \mathrm{mL}$ ) for $24 \mathrm{~h}$. After a $24 \mathrm{~h}$ incubation period, $10 \mu \mathrm{L}$ of MTT solution ( $5 \mathrm{mg} / \mathrm{mL}$ in PBS) was added, followed by $3 \mathrm{~h}$ incubation at $37^{\circ} \mathrm{C}$. Finally, media were aspirated and dimethyl sulfoxide (DMSO, $100 \mu \mathrm{L}$ ) was added to solubilize the formazan salt formed. The optical density was read at $570 \mathrm{~nm}$.

\subsection{Evaluation of Intestinal Transit. Fasted female Swiss} mice were orally treated with vehicle (Veh: water, $1 \mathrm{~mL} / \mathrm{kg}$ ), atropine (Atro: $3 \mathrm{mg} / \mathrm{kg}$, s.c.), or HEAS (100 mg/kg) $30 \mathrm{~min}$ prior to administration of $0.5 \mathrm{~mL}$ of a semisolid marker solution $(0.05 \%$ phenol red plus $1.5 \%$ carboxymethyl cellulose). After $20 \mathrm{~min}$, the mice were euthanized and small intestine was dissected out from the pylorus to the ileocecal junction to the measurement of the intestinal transit. The total length of the small intestine and the distance covered by phenol red solution were then measured. Intestinal transit was expressed in percentage as calculated from IT $=X / Y \times 100$, where $X$ is distance traveled by phenol red and $Y$ is total length of the small intestine.

2.13. Preliminary Toxicological Analysis. Mice were randomly divided into two groups $(n=10)$ and orally treated, once a day for 7 days, with vehicle (water, $10 \mathrm{~mL} / \mathrm{kg}$ ) or HEAS (100 mg/kg, p.o). The animals were observed daily to verify toxic signs of a general nature and the survivors were euthanized at the end of the treatment period. The spleen, liver, heart, lung, kidneys, and liver were excised, dried, and weighed precisely. For each organ, the relative weight was calculated as weight of organ $\times 100$ /body weight of mice on the day of the euthanasia.

2.14. Statistical Analysis. The data were expressed as means \pm SEM. Differences between means were determined by one- or two-way analysis of variance (ANOVA) followed by Bonferroni's post hoc test, when applicable. The MannWhitney test was used in nonparametric data. The software GraphPad Prism $5^{\circledR}$ was used and $P<0.05$ was considered to be significant in all experiments.

\section{Results}

3.1. Phytochemical Analysis. As described above, the phytochemical profile of the HEAS has been previously demonstrated by Barioni et al. [14]. In that occasion, using high performance liquid chromatography (HPLC) system, the two main compounds in HEAS were identified as luteolin and quercetin. Therefore, in this study, to standardize the HEAS, an estimation of the total phenol and flavonoid content was done. Table 3 shows the total phenolic compounds and flavonoid contents in HEAS, which is possible to verify that $200 \mu \mathrm{g}$ of the extract represents $141.03 \pm 1.43 \mu \mathrm{g}$ of tannic acid equivalents and $13.64 \pm 0.74 \mu \mathrm{g}$ of quercetin equivalents.
TABLE 3: Total phenolic content and flavonoid amount of HEAS.

\begin{tabular}{lcc}
\hline Extract $(\mu \mathrm{g})$ & T.A.E. \pm S.E.M. & Q.E. \pm S.E.M. \\
\hline 200 & $141.03 \pm 1.43$ & $13.64 \pm 0.74$ \\
150 & $121.51 \pm 1.82$ & $10.51 \pm 1.07$ \\
100 & $87.14 \pm 0.95$ & $8.45 \pm 0.09$ \\
50 & $46.46 \pm 1.24$ & n.d \\
\hline
\end{tabular}

The results are expressed as means \pm S.E.M. $(n=3)$ of tannic acid equivalents (T.A.E.) in $\mu$ g or quercetin equivalents in $\mu$ g (Q.E.). n.d $=$ not detected.

3.2. HEAS Attenuated the Signs of DSS-Induced Acute Colitis. To evaluate the anti-inflammatory effects of HEAS, we used a mouse model of DSS-induced acute colitis, which mimics the acute phase of human UC. In the same way as Utrilla et al. [19], we analyzed various clinical signs of colitis and quantify such data using the DAI scoring system. As expected, on day 8 , colitic mice treated with vehicle showed $6.3 \%$ loss of body weight (Figure 2(a)) and the DAI score was increased up to 8 , corresponding to severe diarrhea and gross anal bleeding (Figure 3(a)). On the other hand, colitic mice treated with 1,10 , and $100 \mathrm{mg} / \mathrm{kg}$ of HEAS showed loss of body weight (Figure 2(a)) and DAI score significantly lower than colitic group treated with vehicle (Figure 3(a)). Unsurprisingly, the DAI score was also reduced in the colitic group treated with 5-ASA, the positive control drug of the experiment (Figure 3(b)). However, the treatment with 5-ASA did not inhibit the loss of body weight elicited by DSS intake (Figure 2(b)). Figure 3(c) illustrates macroscopic observations of colon after the treatment with vehicle or HEAS $(100 \mathrm{mg} / \mathrm{kg})$. In addition, an improvement of the macroscopic appearance of the colon from colitic mice treated with HEAS $(10 \mathrm{mg} / \mathrm{kg})$ also was observed (data not shown).

Classically in this model, the shortening of the colon length indicates the extent of colon damage in experimental animals. Indeed, as observed in Table 4, noncolitic group showed an average colon length of $102.3 \pm 3.7$, whereas colitic group treated with vehicle exhibited a reduction in colon length to $62.5 \pm 4.0 \mathrm{~mm}$. Additionally, the weight of the colon also was reduced by $46 \%$ in colitic group treated with vehicle when compared with noncolitic group (1.73 \pm $0.07 \mathrm{~g} / 100 \mathrm{~g}$, Table 4). Confirming the beneficial effects of the extract on DSS-induced colitis, HEAS (100 mg/kg) significantly improved the colon length and the weight of the empty colon to $84.0 \pm 3.1 \mathrm{~mm}$ and $1.49 \pm 0.14 \mathrm{~g} / 100 \mathrm{~g}$, respectively (Table 4), and, parallely, was also able to reduce the presence of occult blood in feces (Figure 4). In addition, HEAS, at dose of $10 \mathrm{mg} / \mathrm{kg}$, also diminished the colon shortening evoked by DSS exposure in $19 \%$.

According to Zhang et al. [29], the spleen of mice from colitic group treated with vehicle was markedly swollen, reaching an increase in organ weight of $56 \%$ when compared to noncolitic group $(0.41 \pm 0.02 \mathrm{~g} / 100 \mathrm{~g})$, and this alteration was not detected in colitic mice treated with HEAS at doses of 1 or $100 \mathrm{mg} / \mathrm{kg}$ (Table 4 ). In contrast, no difference in liver weight was perceived between the experimental groups (Table 4).

3.3. HEAS Decreased Histopathological Changes in the Colon Tissue of Mice with DSS-Induced Colitis. The architecture of 
TABLE 4: Effects of HEAS on lenght and weight of colon, and on weight of spleen and liver of DSS-induced colitic mice.

\begin{tabular}{lccccc}
\hline & Treatment & Colon length $(\mathrm{mm})$ & Colon weight $(\mathrm{g} / 100 \mathrm{~g})$ & Spleen weight $(\mathrm{g} / 100 \mathrm{~g})$ & Liver weight $(\mathrm{g} / 100 \mathrm{~g})$ \\
\hline Non-colitic & Vehicle & $102.3 \pm 3.7$ & $1.73 \pm 0.07$ & $0.41 \pm 0.02$ & $4.32 \pm 0.29$ \\
Colitic & Vehicle & $62.5 \pm 4.0^{\mathrm{a}}$ & $0.92 \pm 0.11^{\mathrm{a}}$ & $0.62 \pm 0.06^{\mathrm{a}}$ & $4.48 \pm 0.14$ \\
Colitic & 5-ASA $(100 \mathrm{mg} / \mathrm{kg})$ & $84.0 \pm 3.9^{\mathrm{b}}$ & $1.15 \pm 0.06^{\mathrm{c}}$ & $0.41 \pm 0.03^{\mathrm{b}}$ & $4.56 \pm 0.16$ \\
Colitic & HEAS $(1 \mathrm{mg} / \mathrm{kg})$ & $72.5 \pm 5.1$ & $1.10 \pm 0.04$ & $0.48 \pm 0.04^{\mathrm{b}}$ & $4.53 \pm 0.19$ \\
Colitic & HEAS $(10 \mathrm{mg} / \mathrm{kg})$ & $81.8 \pm 3.7^{\mathrm{b}}$ & $0.95 \pm 0.01$ & $0.53 \pm 0.04$ & $4.47 \pm 0.25$ \\
Colitic & HEAS $(100 \mathrm{mg} / \mathrm{kg})$ & $84.0 \pm 3.1^{\mathrm{b}}$ & $1.49 \pm 0.14^{\mathrm{b}}$ & $0.49 \pm 0.01^{\mathrm{b}}$ & $4.70 \pm 0.38$ \\
\hline
\end{tabular}

${ }^{\mathrm{a}} P<0.001$ versus non-colitic group; ${ }^{\mathrm{b}} P<0.001$ versus colitic group; ${ }^{\mathrm{c}} P<0.05$ versus colitic group.

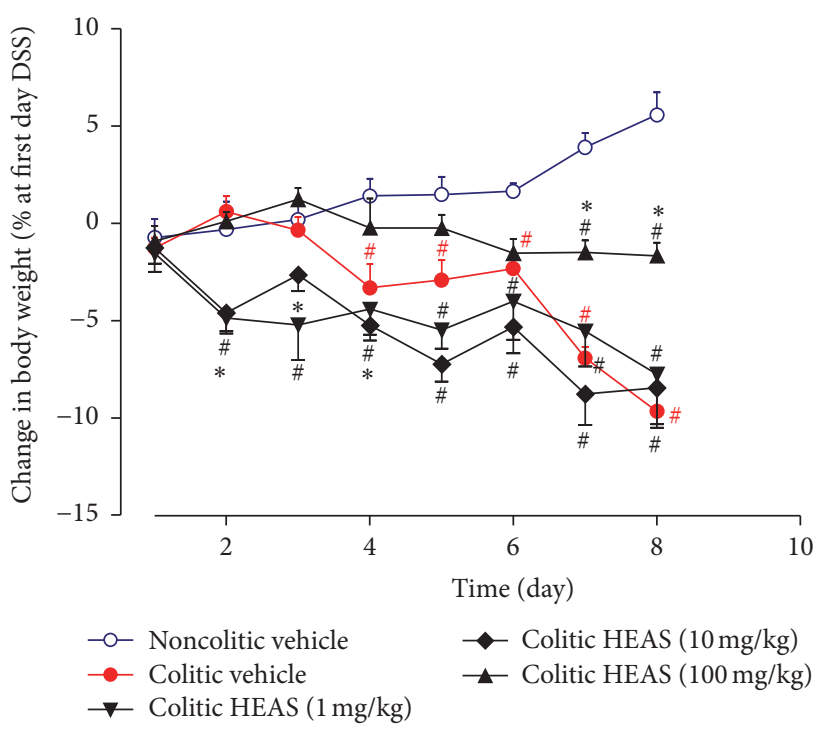

(a)

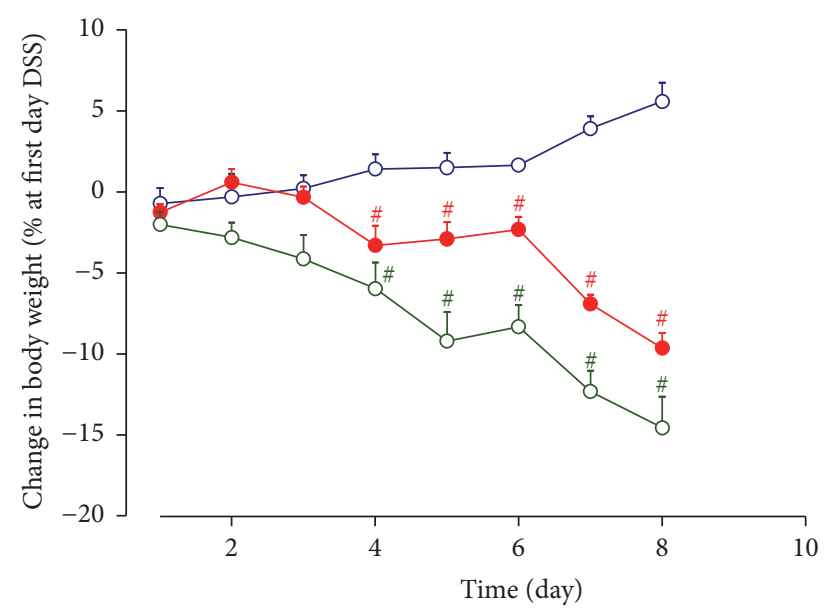

- - Noncolitic vehicle
- - Colitic vehicle
- - Colitic 5-ASA (100 mg/kg)

(b)

Figure 2: Effects of HEAS (1-100 mg/kg, (a)) or 5-ASA (100 mg/kg, (b)) on weight loss evolution. Data are expressed as mean \pm SEM $(n=10)$. Statistical comparison was performed using two-way ANOVA followed by Bonferroni's test. ${ }^{\#} P<0.01$ versus noncolitic group. ${ }^{*} P<0.01$ versus control-colitic group.

the colon from mice of different experimental group was accessed using HE staining. As expected, in noncolitic mice the structures of colon wall, submucosa, and crypts were normal (Figure 5(a)). In contrast, the colon of colitic group treated with vehicle exhibited pathological changes with loss of epithelial barrier, decrease in the number of crypts, and Goblet cells depletion. These pathological changes in colon were ameliorated by HEAS (10 and $100 \mathrm{mg} / \mathrm{kg}$ ) treatment (Figure 5(a)). The microscopic appearance of the colon from colitic mice treated with HEAS $(100 \mathrm{mg} / \mathrm{kg})$ is showed in Figure 5(a). Histological changes were evaluated in samples from the noncolitic group and colitic group treated with vehicle or treated with the extract at a dose of $100 \mathrm{mg} / \mathrm{kg}$, using a standard scoring system. As showed in Figure 5(b), the histopathological scores of HEAS-treated colitic group were significantly lower in relation to colitic group treated with vehicle (Figure 5(b)).

3.4. HEAS Prevents Mucin Depletion in the Colon Tissue of Mice with DSS-Induced Colitis. PAS histochemical staining is a classical technique used to detect the presence of glycoproteins, such as mucins, which are presented within cytoplasmic granules of the Goblet cells and protect the intestinal mucosa. As observed in Figure 6(a), the PAS staining in the colon from colitic mice treated with vehicle was decreased in $69 \%$ when compared to naive group (Veh: $9.88 \pm 1.92 \times 10^{5}$ pixels/field). Interestingly, HEAS $(100 \mathrm{mg} / \mathrm{kg})$ increased the PAS staining by $313 \%$ when compared to colitic vehicle group (Veh: $3.10 \pm$ $0.39 \times 10^{5}$ pixels/field). Microscopic observations of the PAS staining in colonic mucosa from naive, vehicle colitic group, and HEAS $(100 \mathrm{mg} / \mathrm{kg})$ colitic group are represented in Figures 6(b), 6(c), and 6(d), respectively. Besides, the administration of HEAS at $10 \mathrm{mg} / \mathrm{kg}$ also increased significantly the PAS staining at colitic mucosa; on the other hand, the HEAS at $1 \mathrm{mg} / \mathrm{kg}$ was not be able to provoke this increase (data not showed).

3.5. HEAS Improves Oxidative Stress in Colon of Mice with DSS-Induced Colitis. The oxidative stress contributes to intestinal inflammation in IBD patients and in animal models of experimentally induced colitis [30, 31]. In fact, 
TABLE 5: Effects of HEAS on MPO and SOD activity and on GSH and LOOH levels in colon tissue of DSS-induced colitic mice.

\begin{tabular}{lcccccc}
\hline & Treatment & $\begin{array}{c}\text { Dose } \\
(\mathrm{mg} / \mathrm{kg}, \mathrm{p} . \mathrm{o})\end{array}$ & $\begin{array}{c}\mathrm{MPO} \\
(\mathrm{mD} . \mathrm{O} / \mathrm{mg} \text { of } \\
\text { protein) }\end{array}$ & $\begin{array}{c}\text { SOD } \\
(\mathrm{U} / \mathrm{mg} \text { of tissue })\end{array}$ & $\begin{array}{c}\mathrm{GSH} \\
(\mu \mathrm{g} / \mathrm{mg} \text { of } \\
\text { tissue })\end{array}$ & $\begin{array}{c}\text { LOOH } \\
(\mathrm{mmol} / \mathrm{mg} \text { of } \\
\text { tissue })\end{array}$ \\
\hline Non-colitic & Vehicle & - & $1.15 \pm 0.50$ & $1.36 \pm 0.22$ & $797.50 \pm 111.10$ & $2.03 \pm 0.58$ \\
Colitic & Vehicle & - & $4.24 \pm 0.71^{\mathrm{a}}$ & $0.15 \pm 0.03^{\mathrm{a}}$ & $454.70 \pm 78.24^{\mathrm{a}}$ & $3.99 \pm 0.60^{\mathrm{a}}$ \\
Colitic & 5-ASA & 100 & $3.80 \pm 0.24^{\mathrm{a}}$ & $1.10 \pm 0.10^{\mathrm{b}}$ & $424.78 \pm 59.28^{\mathrm{a}}$ & $4.02 \pm 0.29^{\mathrm{a}}$ \\
Colitic & HEAS & 10 & $2.96 \pm 0.11^{\mathrm{a}, \mathrm{b}}$ & $1.35 \pm 0.04^{\mathrm{b}}$ & $444.12 \pm 18.42^{\mathrm{a}}$ & $3.52 \pm 0.42^{\mathrm{a}}$ \\
Colitic & HEAS & 100 & $1.26 \pm 0.36^{\mathrm{b}}$ & $1.36 \pm 0.64^{\mathrm{b}}$ & $482.70 \pm 62.52^{\mathrm{a}}$ & $4.14 \pm 0.34^{\mathrm{a}}$ \\
\hline
\end{tabular}

${ }^{\mathrm{a}} \mathrm{P}<0.001$ versus non-colitic vehicle group, ${ }^{\mathrm{b}} \mathrm{P}<0.01$ versus colitic vehicle group.

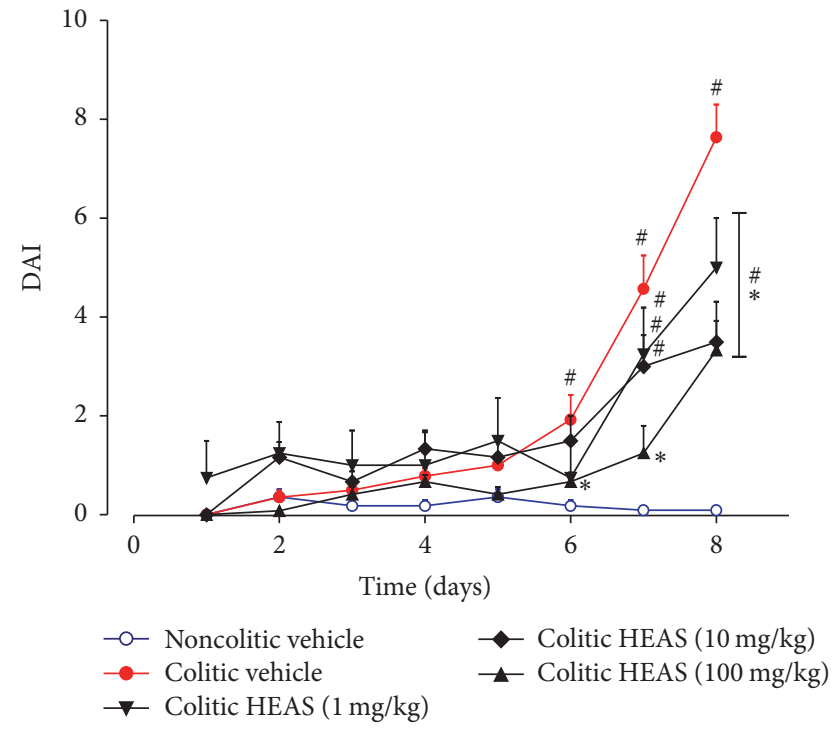

(a)

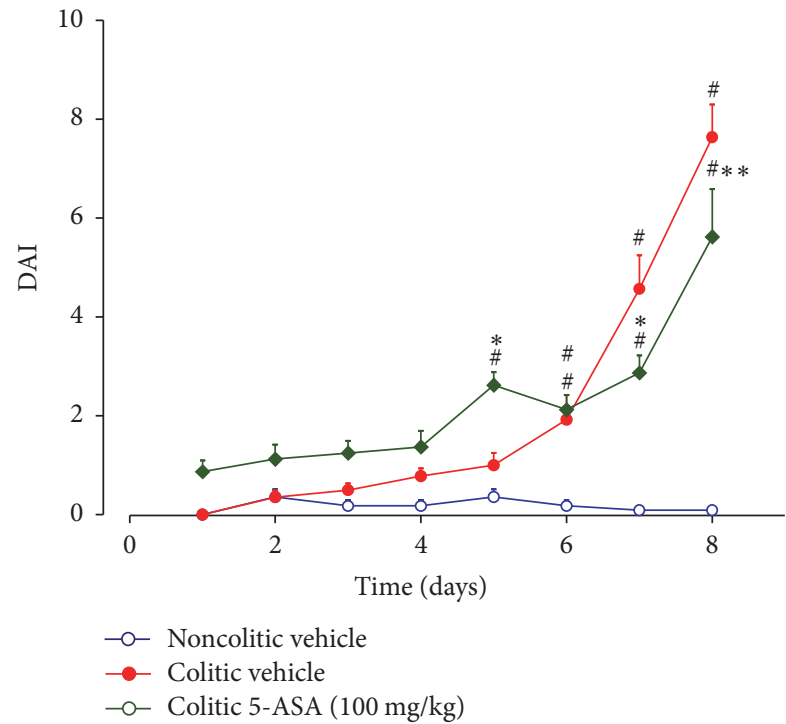

(b)

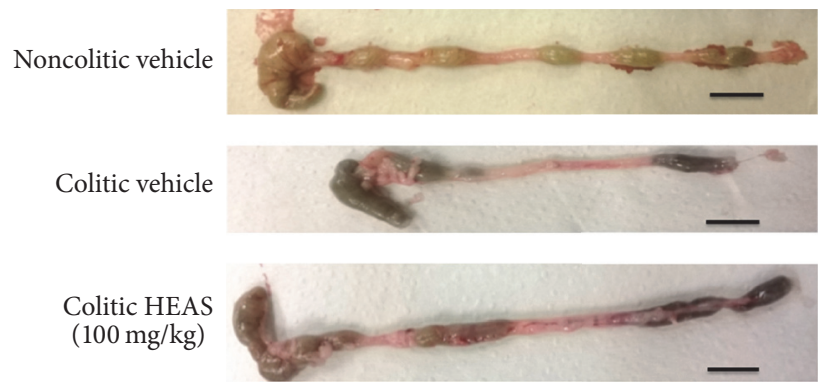

(c)

Figure 3: Effects of HEAS (1-100 mg/kg (a)) or 5-ASA (100 mg/kg (b)) on DAI values over the whole experimental period. (c) Macroscopic appearance of colon from mice treated with vehicle or HEAS $(100 \mathrm{mg} / \mathrm{kg})$. Data are expressed as mean \pm SEM $(n=10)$. Statistical comparison was performed using two-way ANOVA followed by Bonferroni's test. ${ }^{\#} P<0.01$ versus noncolitic group. ${ }^{* *} P<0.01$ and ${ }^{*} P<0.01$ and versus control-colitic group.

the availability of the antioxidant GSH and the SOD activity were decreased in colon tissue of colitic mice treated with vehicle in $43 \%$ and $89 \%$, respectively, when compared to noncolitic group $(797.50 \pm 111.10 \mu \mathrm{g}$ of $\mathrm{GSH} / \mathrm{mg}$ of tissue and $1.36 \pm 0.22 \mathrm{U} \mathrm{SOD} / \mathrm{mg}$ of protein) (Table 5). Additionally, LOOH levels were increased in $97 \%$ in colitic mice treated with vehicle, when compared to noncolitic group $(2.03 \pm$ $0.58 \mathrm{mmol}$ of $\mathrm{LOOH} / \mathrm{mg}$ of tissue, Table 5$)$. The treatment with HEAS (10 or $100 \mathrm{mg} / \mathrm{kg})$ or 5-ASA $(100 \mathrm{mg} / \mathrm{kg})$ did not change GSH or LOOH levels in colon tissue but fully restored the SOD activity to basal levels, as demonstrated in Table 5.

3.6. HEAS Features Scavenger Effect of Free Radicals. Corroborating the in vivo antioxidant capacity of HEAS, the in vitro DPPH assay showed that HEAS concentration dependently scavenged DPPH radicals, with a $\log \mathrm{IC}_{50}=2.4$ (Figure 7 ). 


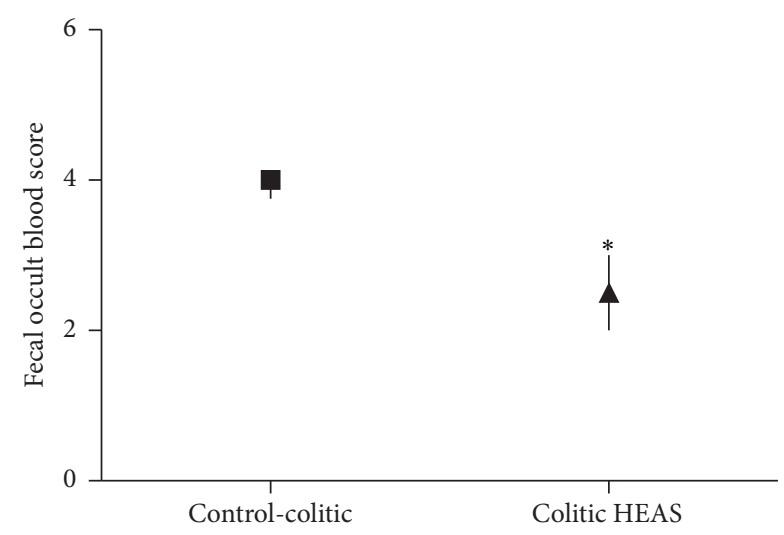

FIGURE 4: Effects of HEAS (100 mg/kg) on fecal occult blood score in DSS-induced colitic mice. Data are expressed as median \pm interquartile range of triplicated experiments. Statistical comparison was performed using Mann-Whitney test. ${ }^{*} P<0.05$ versus controlcolitic group.

As expected, ascorbic acid (the standard control) reduced DPPH levels by $70.74 \%$ when compared with vehicle $(22.01 \pm$ $1.24 \mu \mathrm{M}$; Figure 7).

3.7. HEAS Decreases the MPO Activity in the Colon Tissue of Mice with DSS-Induced Colitis. MPO is an enzyme present in neutrophils and in smaller quantities in monocytes and macrophages. Classically, the MPO activity is used as a marker of acute inflammation by its relation to the degree in neutrophil infiltration. The MPO activity in colonic tissues of colitic mice treated with vehicle was increased up to $268 \%$, when compared to noncolitic group $(1.15 \pm 0.50 \mathrm{mD} . \mathrm{O} / \mathrm{mg}$ of protein) (Table 5). On the other hand, the treatment with HEAS $(10 \mathrm{mg} / \mathrm{kg})$ reduced the MPO activity in $30 \%$, whereas the treatment with the extract, at the highest dose $(100 \mathrm{mg} / \mathrm{kg})$, was able to restore the levels of this parameter to basal values (Table 5). Nevertheless, the treatment with 5-ASA $(100 \mathrm{mg} / \mathrm{kg})$ did not significantly reduce the MPO activity, compared to vehicle colitic group.

\subsection{HEAS Decreases TNF- $\alpha$ and IL-6 Levels and Increases} IL-10 Levels in the Colon of Mice with DSS-Induced Colitis. DSS administration significantly increased the levels of TNF$\alpha$ (Figure 8(a)) and IL-6 (Figure 8(b)) in colon tissue by 193 and $726 \%$ in relation to the noncolitic group (64.85 \pm $16.55 \mathrm{pg} / \mathrm{mL}$ and $61.10 \pm 11.55 \mathrm{pg} / \mathrm{mL}$, resp.). In contrast, DSS treatment decreased the content of IL-10 (Figure $8(\mathrm{c})$ ) in colon in $61 \%$, when compared to noncolitic group (1144.01 \pm $138.10 \mathrm{pg} / \mathrm{mL})$. The treatment with HEAS, at doses of 10 and $100 \mathrm{mg} / \mathrm{kg}$, reduced the levels of TNF (Figure 8(a)) in 46 and $62 \%$, respectively, compared to colitic vehicle group. Similarly, the levels of IL-6 (Figure 8(b)) were decreased in 62 and $75 \%$ in colitic mice treated with HEAS, at doses of 10 and $100 \mathrm{mg} / \mathrm{kg}$, respectively, related to colitic vehicle group. In addition, the daily administration of HEAS $(100 \mathrm{mg} / \mathrm{kg})$ increased the levels of IL-4 (Figure $8(\mathrm{~d})$ ) and IL-10 (Figure $8(\mathrm{c}))$ in 40 and $112 \%$, respectively, when compared to vehicle group exposed to DSS.
3.9. HEAS Reduces the LPS-Induce NO Production in Isolated Rat Peritoneal Macrophage. To investigate whether HEAS has an anti-inflammatory activity, NO production was determined in the presence of the extract at 1,10 , or $100 \mu \mathrm{g} / \mathrm{mL}$ in LPS-induced peritoneal macrophages. When LPS were incubated to peritoneal macrophages, the nitrite (a surrogate of NO production) generation dramatically increased from the basal level of 8.54 to $37.97 \mu \mathrm{M}$ after $24 \mathrm{~h}$ incubation (Figure 9(a)). LPS-induced nitrite generation was significantly and concentration dependently attenuated by HEAS up to $50 \%$ at $100 \mu \mathrm{g} / \mathrm{mL}$ (Figure 9(a)). In addition, this inhibitory effect of HEAS was not triggered by nonspecific cytotoxicity, because the extract had no effect on cell viability as determined by MTT assay at concentrations from 1 to $100 \mu \mathrm{g} / \mathrm{mL}$ (Figure 9(b)).

3.10. HEAS Unchanged the Intestinal Transit in Mice. The rate of intestinal transit of semisolid phenol red after $15 \mathrm{~min}$ in control mice was $62.33 \pm 3.56 \%$ and the oral treatment with HEAS $(100 \mathrm{mg} / \mathrm{kg})$ did not modify this parameter. Expectedly, atropine (the positive control) reduced this rate to $21.02 \pm 5.20 \%$ (Figure 10 ).

3.11. HEAS Did Not Promote Any Signs of Toxicity in Mice. The oral administration of HEAS $(100 \mathrm{mg} / \mathrm{kg})$ did not promote any signs of toxicity in mice and in accordance did not change the body weight (Figure 11(a)) or the organ weight (Figure 11(b)) of mice, comparable to the vehicle treated group.

\section{Discussion}

In our previous studies, the hydroalcoholic extract of inflorescences of $A$. satureioides (HEAS) displayed gastroprotective effect against different harmful agents, without signs of toxicity after its administration at a dose of $2000 \mathrm{mg} / \mathrm{kg}$ [15, 32]. In agreement, the ability of this extract to inhibit neutrophil functions related to the innate response has also been described [14]. In the current trial, the intestinal antiinflammatory effect of HEAS was confirmed in a mouse model of DSS-induced colitis. DSS intake was intended to induce clinical features in mice that are similar to mild colitis, including impaired barrier function, intestinal epithelial cell inflammation, and oxidative stress [33]. We found that HEAS improves DSS-induced experimental colitis by reduction of inflammatory and oxidative damage in colon, in a dose dependent-manner, mainly through the attenuation of inflammatory cytokines production and the improvement of intestinal mucin barrier.

The inflorescences of $A$. satureioides have traditionally been used in South American countries to prevent diseases and reduce inflammation, including gastrointestinal disorders [9]. Numerous studies have reported the bioactive properties of A. satureioides, including antioxidant [34], antimicrobial [35], anti-inflammatory [11, 13, 14], gastroprotective $[15,32]$, insecticidal [36], antiherpetic [37], and trypanocidal [38] activities. The functional properties of natural agents are associated with their phytochemistry composition and 

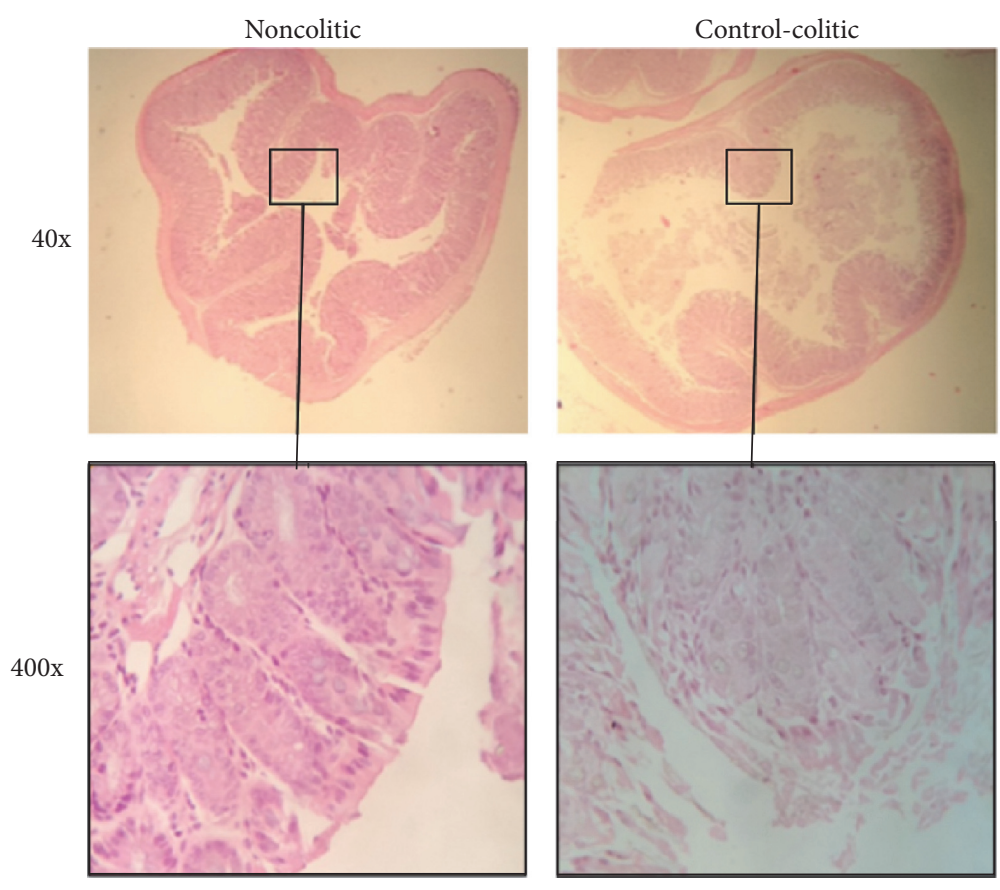

(a)
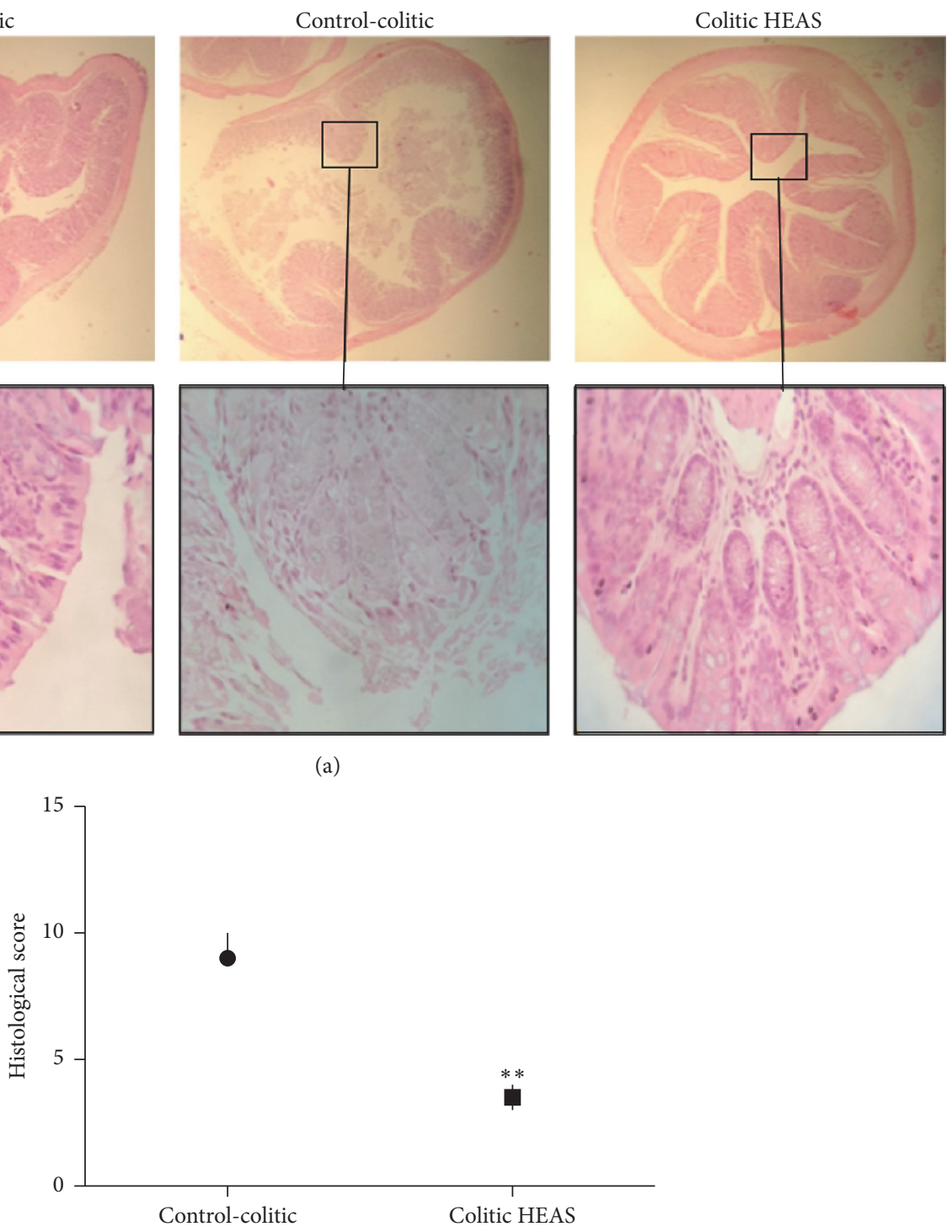

(b)

FIGURE 5: Effects of HEAS (100 mg/kg) on histological changes in colon tissue of DSS-induced colitic mice. (a) Representative images of all groups. (b) Values of histological changes. Data are expressed as median \pm interquartile range $(n=10)$. Statistical comparison was performed using Mann-Whitney test. ${ }^{* *} P<0.01$ versus control-colitic group.

the presence of the main compounds luteolin (yield 2.28\%) (Figure 12(a)) and quercetin (yield 2.53\%) (Figure 12(b)) was previously confirmed by phytochemicals analysis [14, 32]; besides, GC-MS analysis showed that HEAS also contains steroids and fatty acids [14]. Indeed, the intestinal antiinflammatory activity of luteolin [38] and quercetin [39] was confirmed by in vivo and in vitro experiments. In this study, the total phenol and flavonoids in HEAS were measured revealing that the amount of these compounds represents $70.51 \%$ and $6.82 \%$ of HEAS, respectively. The flavonoids are pointed out as having beneficial effects to treat IBD [40]. The luteolin plus quercetin content in HEAS was previously reported by Barioni et al. [14] equal to $4.81 \%$, which is consistent with the total flavonoid content reported in the results of this study. Thus, these findings confirmed and extended the phytochemical profile of the extract, contributing quantitative data to the validation of herbal product from inflorescences of $A$. satureioides to treat IBD based on flavonoid content.

Based on these observations, we hypothesized that HEAS presents anti-inflammatory effect against experimental colitis and may represent a source of a new herbal product based on traditional knowledge for the treatment of IBD. As expected, the results of DAI and the findings of histological examination confirmed this purpose. Furthermore, the results showed in this study pointed out beneficial effects of the extract in DAI values even at the lowest dose.

In the colitis induced by DSS intake, the positive control agent used was 5-ASA, which is anti-inflammatory aminosalicylate used in the management of IBD in humans [41]. 


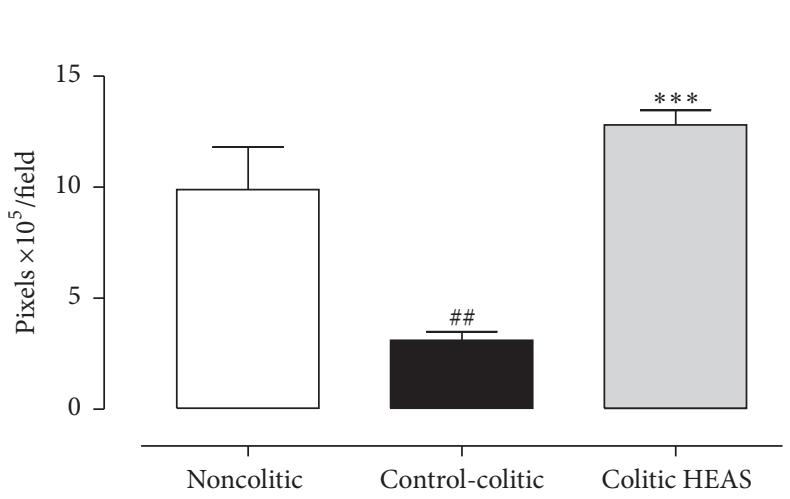

(a)

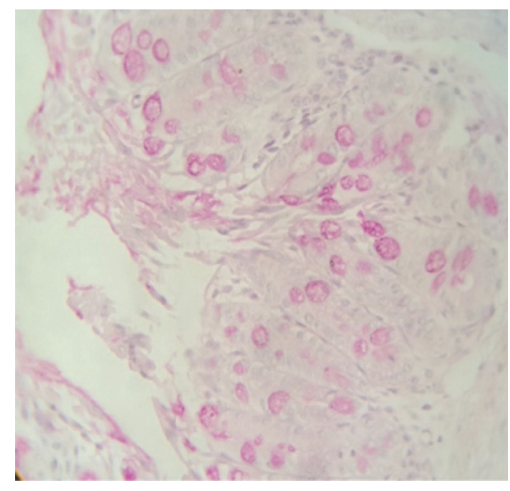

(c)

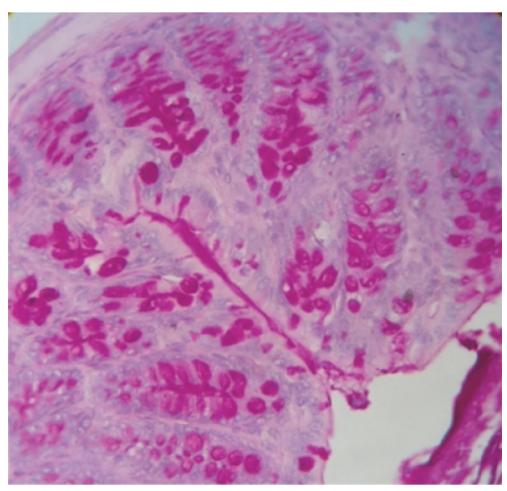

(b)

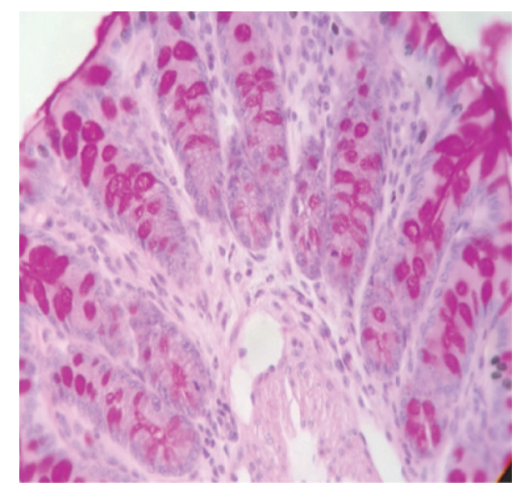

(d)

FIGURE 6: Effects of HEAS (100 mg/kg) on colonic staining for mucin-like glycoproteins. (a) Mucin staining is expressed as mean \pm SEM $(n=10)$; statistical comparison was performed using one-way ANOVA followed by Bonferroni's test; ${ }^{\# \# ~} P<0.01$ versus noncolitic group and ${ }^{* * *} P<0.001$ versus control-colitic group. Representative image of noncolitic group in (b), control-colitic group in (c), and colitic HEAS group in (d). ((b)-(d)) Magnification $=400 \mathrm{x}$.

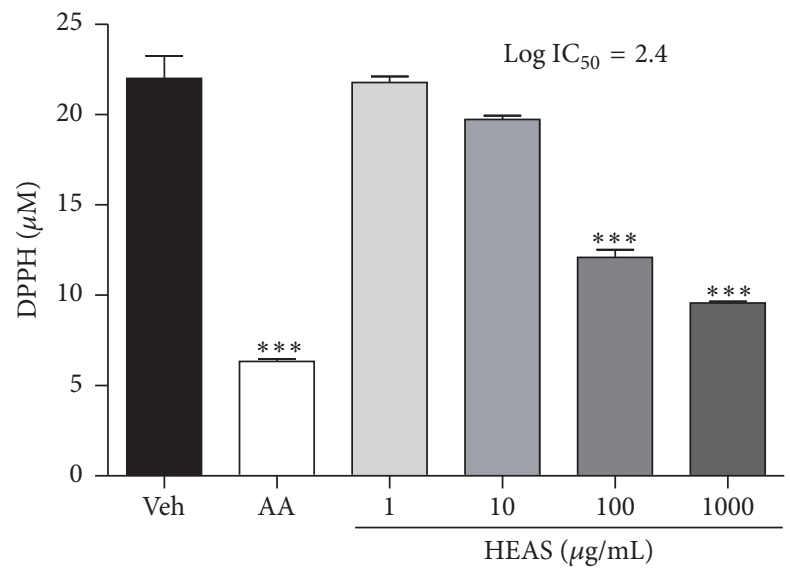

FIGURE 7: In vitro ability of HEAS $(1-1000 \mu \mathrm{g} / \mathrm{mL})$ to scavenge the free radical DPPH. The results are expressed as mean \pm SEM of triplicated experiments. Statistical comparison was performed using one-way ANOVA followed by Dunnett's test. ${ }^{* * *} P<0.001$ versus vehicle group (Veh). AA: ascorbic acid $(50 \mu \mathrm{g} / \mathrm{mL})$.

Unsurprisingly, the treatment with 5-ASA improved DAI scores and these findings improve the accuracy and the validity of the experimental results showed in this study.

The spleen is a peripheral immune organ with a wide variety of immune cells; it is known that a number of infections and diseases can contribute to an enlarged spleen tissue [42]. Regarding colitis, Zhang et al. [29] have reported that the spleen is markedly swollen in DSS colitic animals. Thus, increased spleen weight generally correlates with the extent of inflammation and anemia in this model [18]. Our study also detected an augmented spleen weight in DSSinduced colitis in mice, which was prevented by HEAS treatment. In view of the above observation, we can infer that HEAS has benefic effects on the immune response to the whole body.

A continuously secreted mucus layer formed by high molecular weight oligomeric mucin glycoproteins, which exert important role in mucosal defense [43], lines the gastrointestinal tract. Nowadays there are many reasons to believe that the damage in mucosal barrier is critically important to the pathogenesis of IBD [44]. Herein, the colonic mucin levels were quantified based upon their PAS reactivity and this measurement confirmed the depletion in Goblet cells at DSS-injured colon. Consistent with the improvement evoked by HEAS in inflamed colon, the depletion in mucin content was minimized in the group treated with the extract $(100 \mathrm{mg} / \mathrm{kg})$. It is known that injuries in mucosal barrier function are linked to modifications in macromolecules permeability by colonic epithelium, increasing bacterial invasion and/or translocation [45]. These events can trigger the release of inflammatory and oxidative mediators, leading to the 


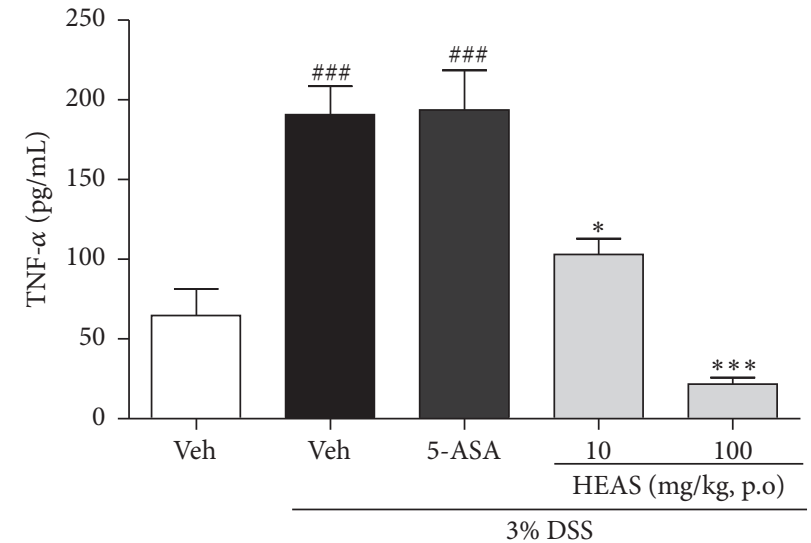

(a)

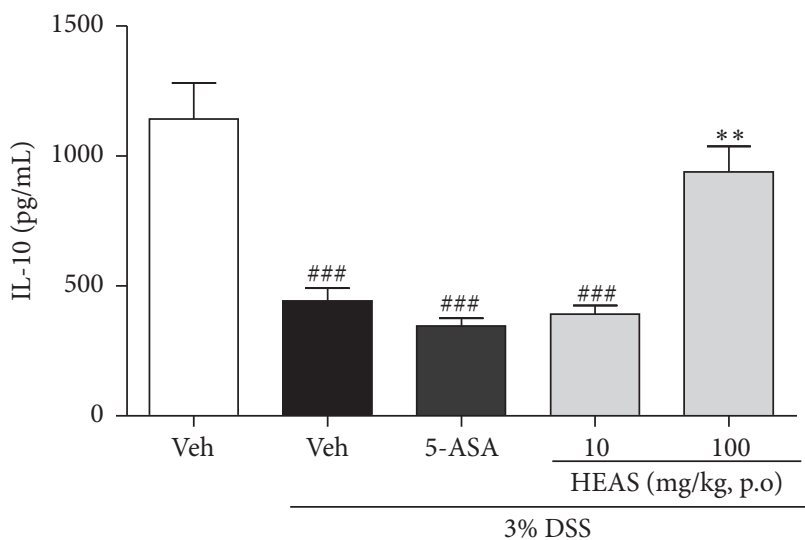

(c)

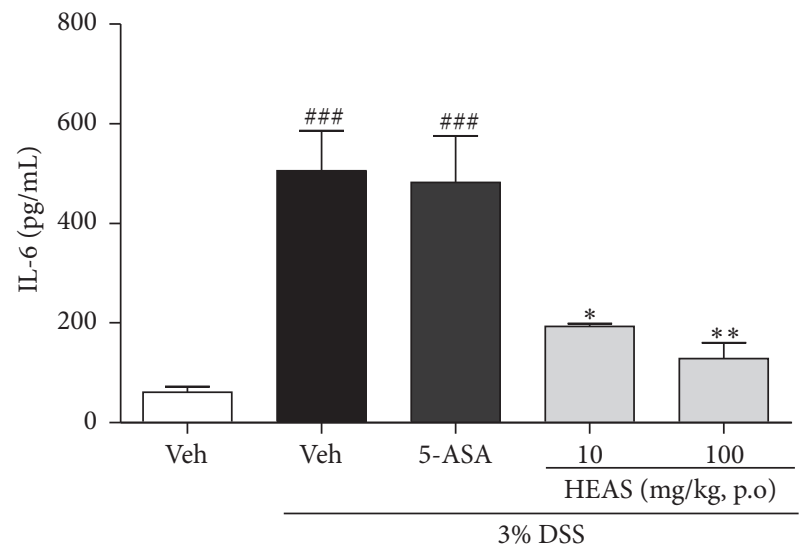

(b)

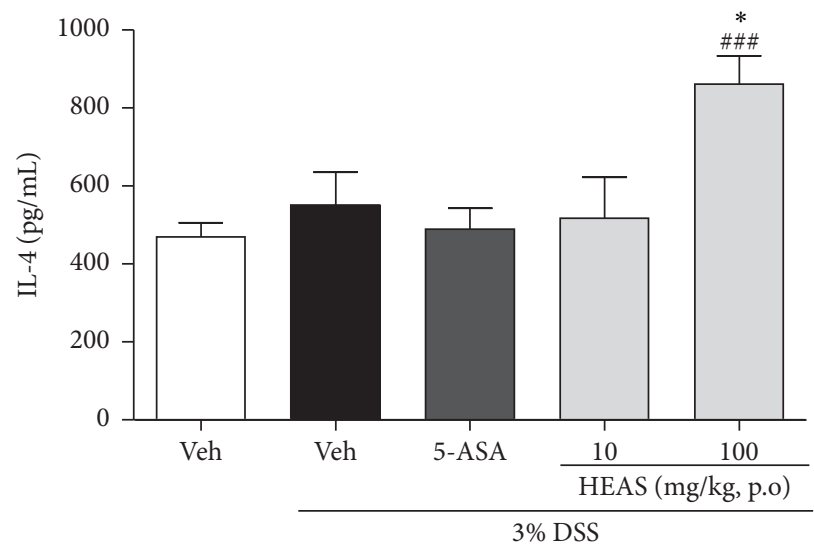

(d)

FIGURE 8: Effects of HEAS (100 mg/mL) on TNF- $\alpha$ (a), IL-6 (b), IL-10 (c), and IL-4 (d) levels in colon tissue of DSS-induced colitic mice. The results are expressed as mean \pm SEM $(n=10)$. Statistical comparison was performed using one-way ANOVA followed by Bonferroni's test. ${ }^{\# \# \#} P<0.001$ versus noncolitic group. ${ }^{*} P<0.05,{ }^{* *} P<0.01$, and ${ }^{* * *} P<0.001$ versus control-colitic group.

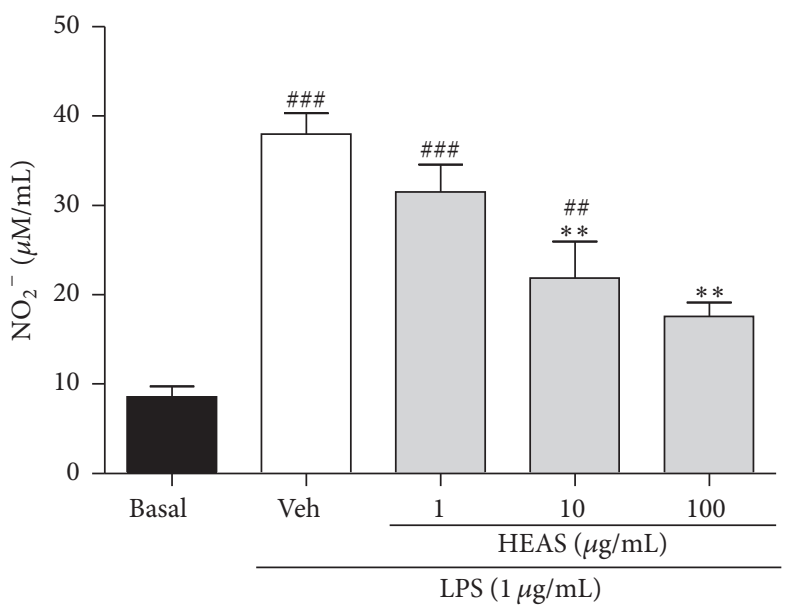

(a)

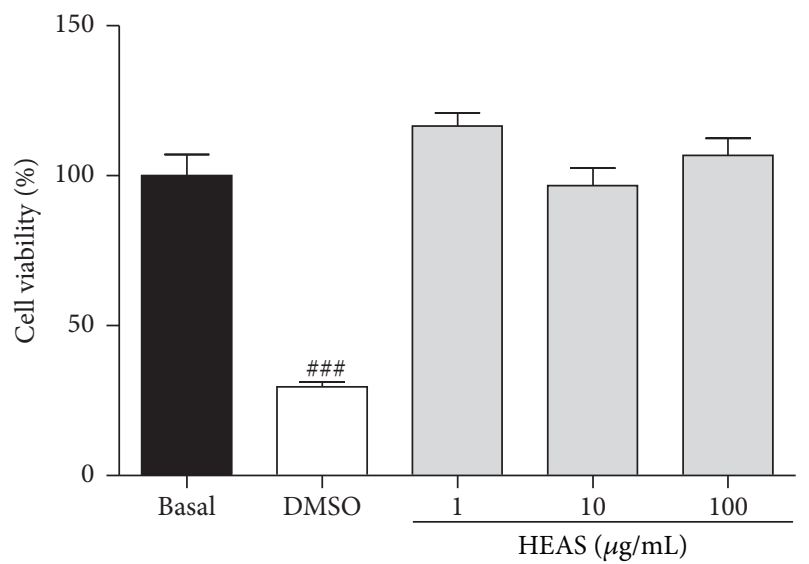

(b)

FIGURE 9: Effects of HEAS (1-100 $\mu \mathrm{g} / \mathrm{mL})$ on the LPS induced NO production in isolated rat peritoneal macrophage (a) and on the cellular viability (b). The results are expressed as mean \pm SEM of triplicated experiments. Statistical comparison was performed using one-way ANOVA followed by Bonferroni's test. ${ }^{\# \# \#} P<0.001$ and ${ }^{\# \#} P<0.01$ versus basal group. ${ }^{* *} P<0.01$ versus vehicle group (Veh). 


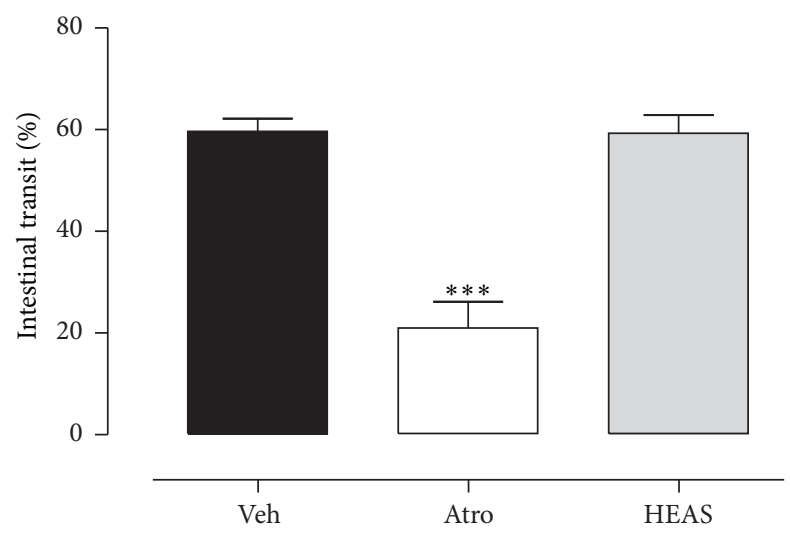

FIGURE 10: Effects of HEAS (100 mg/mL) on intestinal transit rate of mice. The results are expressed as mean $\pm \operatorname{SEM}(n=8)$. Statistical comparison was performed using one-way ANOVA followed by Bonferroni's test. ${ }^{* * *} P<0.001$ versus vehicle group (Veh).

damage in colon; in contrast, the maintenance of the integrity of the mucin barrier promoted by protective effects of HEAS could result in a primary event in beneficial mode of action of this extract.

Oxidative stress plays an important role in the pathogenesis of inflammatory bowel diseases and occurs when the production of reactive oxygen species (ROS) exceeds tissue antioxidant resources [46]. In inflamed colonic tissue, ROS are produced by activated neutrophils and macrophage and its production can be inferred by measuring the levels of LOOH [47]. In fact, colitic mice treated with vehicle exhibited increased $\mathrm{LOOH}$ content and this change was accompanied by reduction in GSH levels, a nonenzymatic antioxidant defense. In addition, similarly to Zhao et al. [48], the SOD activity was reduced in colon tissue from colitic mice treated with vehicle. SOD is metal ion cofactor-requiring enzymes that catalyze dismutation of superoxide anion $\left(\mathrm{O}_{2}{ }^{-}\right)$into molecular oxygen $\left(\mathrm{O}_{2}\right)$ and hydrogen peroxide $\left(\mathrm{H}_{2} \mathrm{O}_{2}\right)$ [47]. Collectively, these findings characterized intense oxidative damage at colonic sites caused by DSS intake. Considering the effects of HEAS, the measurement of oxidative parameters was performed in samples from colitic mice treated with HEAS at doses of 10 and $100 \mathrm{mg} / \mathrm{kg}$, but not $1 \mathrm{mg} / \mathrm{kg}$. On the other hand, treatment with HEAS (10 and $100 \mathrm{mg} / \mathrm{kg}$ ) promoted beneficial effects in SOD activity and in LOOH content in samples from colitic mice. However, HEAS treatment did not elicit any effect on GSH depleted levels. Nevertheless, the in vitro DPPH radical scavenging profile presented by HEAS confirmed its scavenging effect and is likely, but not yet proven, that this ability compensates the depleted GSH. Moreover, the reduction in $\mathrm{LOOH}$ in colonic tissue is a remarkable evidence of the improvement of intracellular redox status during the anti-inflammatory action promoted by HEAS.

In addition, HEAS (10 and $100 \mathrm{mg} / \mathrm{kg}$ ) also reduced neutrophils infiltration in colon tissues, which was evidenced by reduction in MPO activity. MPO is an index of neutrophil recruitment in the DSS-induced colitis model and in consequence reflects the inflammatory events in parallel with cytokine concentrations. Indeed, the colonic MPO activity was significantly increased in the colitic vehicle treated group compared with the noncolitic group, which was decreased by HEAS treatment. These results extend and reinforce those described by Barioni et al. [14], at which the administration of $A$. satureioides extract reduced in vivo LPS neutrophil influx to the exudates at air pouch model and the number of rolling and adhered leukocytes in LPS-stimulated mesentery. In addition, the authors have confirmed that the in vivo treatment with $A$. satureioides extract modifies the adhesive properties of neutrophils to the endothelium, which then impair their migration into inflamed tissue. Accordingly, HEAS also reduced neutrophil infiltration into injured colon tissue and we can suggest that these effects described by Barioni et al. [14] are also involved in the intestinal antiinflammatory actions elicited by HEAS.

The complete etiology of IBD is unknown, but there is a consensus that along with the increased recruitment of leukocytes to the site of inflammation, also there is an imbalanced production of proinflammatory mediators [49]. Particularly, the increase in inflammatory cytokines secretion in intestinal mucosal is unselectively increased in both ulcerative colitis and Crohn's disease [50]. In accordance to that previously demonstrated by Sreedhar et al. [51], DSS intake induced an increase in colonic TNF- $\alpha$ and IL- 6 levels, which was associated with colon damage. However, in our results the levels of Th2 cytokine IL-4 were not significantly increased $(P=0.1582)$ in colitic mice. In agreement, no difference was found in IL-4 release in experimental colitis by Dieleman et al. [52] and by Barros et al. [53] in the acute phase of ulcerative colitis. Interestingly, the treatment with HEAS, at the major dose tested, promoted an increase in IL-4 levels. Furthermore, reinforcing the beneficial effects of HEAS, the treatment with the extract, at doses of 10 and $100 \mathrm{mg} / \mathrm{kg}$, decreased TNF- $\alpha$ and IL- 6 content in colon tissue at basal levels. Moreover, it is described that IL-10 acts as a key mediator for maintaining gut homeostasis and that sequence variants in the IL-10 locus contribute to UC. In accordance, HEAS $(100 \mathrm{mg} / \mathrm{kg})$ treatment also normalized the secretion of IL-10. IL-10 is an immunoregulatory cytokine involved in the innate and cell-mediated response [54]. It promotes the downregulation of colon inflammation by the inhibition of both antigen presentation and release of proinflammatory cytokines [55] and is directly related to regulatory cells activity [56].

In vitro analyses related to the anti-inflammatory effects of HEAS also were performed. Macrophage activation induced by LPS increased the production of proinflammatory cytokines and inflammatory mediators, including NO. Indeed this effect was assessed in our study and HEAS was able to inhibit NO production in LPS-stimulated peritoneal macrophages. Cytotoxicity assay performed with HEAS incubation indicated that the extract even at dose of $100 \mu \mathrm{g} / \mathrm{mL}$ did not affect the viability of peritoneal macrophages. Therefore, suppressive effects in NO production are not due to its cytotoxic effects. On the basis of the in vitro study, the inhibition of the NO production by HEAS can be a result from the suppression of the enzymatic activities and/or expression levels of inducible nitric oxide synthase isoform. 


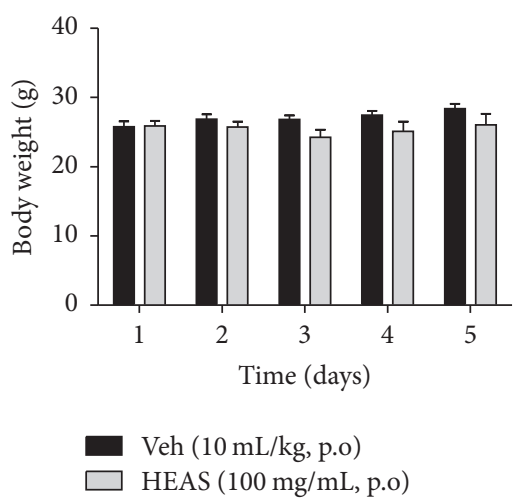

(a)

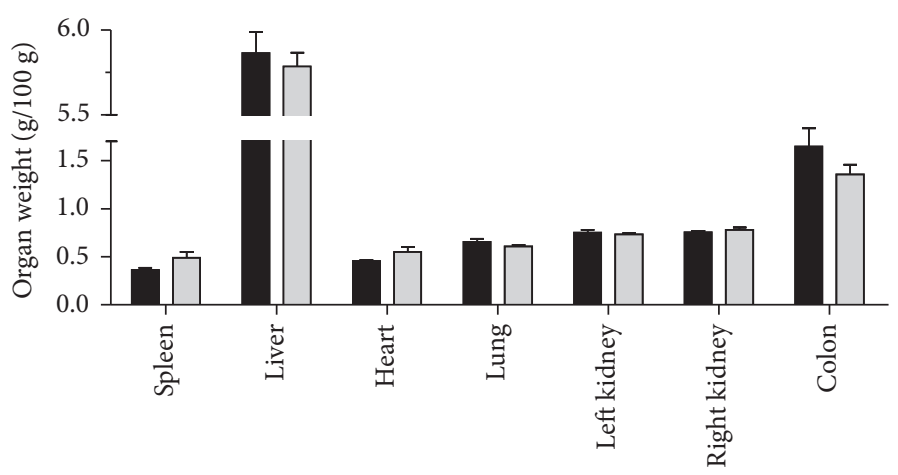

(b)

Figure 11: Effects of HEAS $(100 \mathrm{mg} / \mathrm{mL})$ on the body weight (a) and on the relative organs weight (b) of mice. The results are expressed as mean \pm SEM $(n=10)$. Statistical comparison was performed using two-way ANOVA followed by Bonferroni's test.<smiles>O=c1cc(-c2ccc(O)c(O)c2)oc2cc(O)cc(O)c12</smiles>

(a)<smiles>O=c1c(O)c(-c2ccc(O)c(O)c2)oc2cc(O)cc(O)c12</smiles>

(b)

FIgURE 12: (a) Luteolin structure; (b) quercetin structure.

Furthermore, DSS-induced colitis might be improved by suppressing macrophage activation through HEAS treatment. This hypothesis is especially strengthened by the elevated IL4 levels found in colon samples from colitic mice treated with HEAS $(100 \mathrm{mg} / \mathrm{kg})$.

Regarding the experiment evaluating intestinal motility, HEAS administration at the same dose that reduces inflammation associated with DSS-induced colitis did not produce any change in intestinal transit rate. This result is important since it indicates that HEAS effects, especially in diarrhea parameter, are not associated with a reduction in intestinal motility. Taking into account that the reduction in the body and in the relative organs weight is a simple and sensitive marker of toxicity of substances, the data obtained here provide preliminary information about the safety of the HEAS.

\section{Conclusion}

The hydroalcoholic extract of inflorescences of A. satureioides displayed intestinal anti-inflammatory activity in the DSSinduced colitis model by the maintenance of intestinal mucin barrier, reducing the neutrophil migration and macrophage activation, and consequently the oxidative damage, in parallel to the adjustment in the levels of pro- and anti-inflammatory cytokines. Together, these results suggest $A$. satureioides as a promising source of herbal medicine that could be used in treatment of the inflammatory bowel disease. Besides, this work corroborates the popular use of $A$. satureioides in inflammatory disorders.

\section{Competing Interests}

The authors declare that they have no conflict of interests.

\section{Acknowledgments}

The authors are grateful to Conselho Nacional de Desenvolvimento Científico e Tecnológico (CNPq), Coordenação de Aperfeiçoamento de Pessoal de Nível Superior (CAPES), Fundação de Apoio à Pesquisa Científica e Tecnológica do Estado de Santa Catarina (FAPESC), and Universidade do Vale do Itajaí (UNIVALI).

\section{References}

[1] B. C. Da Silva, A. C. Lyra, R. Rocha, and G. O. Santana, "Epidemiology, demographic characteristics and prognostic predictors of ulcerative colitis," World Journal of Gastroenterology, vol. 20, no. 28, pp. 9458-9467, 2014. 
[2] N. A. Molodecky, I. S. Soon, D. M. Rabi et al., "Increasing incidence and prevalence of the inflammatory bowel diseases with time, based on systematic review," Gastroenterology, vol. 142, no. 1, pp. 46-54.e42, 2012.

[3] A. Di Sabatino, P. Biancheri, L. Rovedatti, T. T. MacDonald, and G. R. Corazza, "Recent advances in understanding ulcerative colitis," Internal and Emergency Medicine, vol. 7, no. 2, pp. 103111, 2012.

[4] A. Kornbluth and D. B. Sachar, "Ulcerative colitis practice guidelines in adults: American college of gastroenterology, practice parameters committee," The American Journal of Gastroenterology, vol. 105, no. 3, pp. 501-523, 2010.

[5] J. D. Feuerstein and A. S. Cheifetz, "Ulcerative colitis: epidemiology, diagnosis, and management," Mayo Clinic Proceedings, vol. 89, no. 11, pp. 1553-1563, 2014.

[6] C. Bezzio, F. Furfaro, R. De Franchis, G. Maconi, A. K. Asthana, and S. Ardizzone, "Ulcerative colitis: current pharmacotherapy and future directions," Expert Opinion on Pharmacotherapy, vol. 15, no. 12, pp. 1659-1670, 2014.

[7] H. Sales-Campos, P. J. Basso, V. B. F. Alves et al., "Classical and recent advances in the treatment of inflammatory bowel diseases," Brazilian Journal of Medical and Biological Research, vol. 48, no. 2, pp. 96-107, 2015.

[8] G. Ferraro, C. Anesini, A. Ouviña et al., "Total phenolic content and antioxidant activity of extracts of Achyrocline satureioides flowers from different zones in Argentina," Latin American Journal of Pharmacy, vol. 27, no. 4, pp. 626-628, 2008.

[9] M. Bolson, S. R. Hefler, E. I. Dall'Oglio Chaves, A. Gasparotto Junior, and E. L. Cardozo Junior, "Ethno-medicinal study of plants used for treatment of human ailments, with residents of the surrounding region of forest fragments of Paraná, Brazil," Journal of Ethnopharmacology, vol. 161, pp. 1-10, 2015.

[10] C. Kadarian, A. M. Broussalis, J. Miño et al., "Hepatoprotective activity of Achyrocline satureioides (Lam) D. C.," Pharmacological Research, vol. 45, no. 1, pp. 57-61, 2002.

[11] M. Cosentino, R. Bombelli, E. Carcano et al., "Immunomodulatory properties of Achyrocline satureioides (Lam.) D.C. infusion: a study on human leukocytes," Journal of Ethnopharmacology, vol. 116, no. 3, pp. 501-507, 2008.

[12] L. Taylor, The Healing Power of Rainforest Herbs-A Guide to Understanding and Using Herbal Medicinals, Square One, Garden City Park, NY, USA, 2005.

[13] C. M. O. Simões, E. P. Schenkel, L. Bauer, and A. Langeloh, "Pharmacological investigations on Achyrocline satureioides (Lam.) DC., compositae," Journal of Ethnopharmacology, vol. 22, no. 3, pp. 281-293, 1988.

[14] E. D. Barioni, J. R. Santin, I. D. Machado et al., "Achyrocline satureioides (Lam.) D.C. hydroalcoholic extract inhibits neutrophil functions related to innate host defense," Evidence-Based Complementary and Alternative Medicine, vol. 2013, Article ID 787916, 12 pages, 2013.

[15] J. R. Santin, M. Lemos, L. C. K. Júnior, R. Niero, and S. F. de Andrade, "Antiulcer effects of Achyrocline satureoides (Lam.) DC (Asteraceae) (Marcela), a folk medicine plant, in different experimental models," Journal of Ethnopharmacology, vol. 130, no. 2, pp. 334-339, 2010

[16] A. Arnous, D. P. Makris, and P. Kefalas, "Effect of principal polyphenolic components in relation to antioxidant characteristics of aged red wines," Journal of Agricultural and Food Chemistry, vol. 49, no. 12, pp. 5736-5742, 2001.

[17] J. L. Lamaison, C. Petijean-Freytet, and A. Carnat, "Teneurs en acide rosmarinique, en dérivés hydroxycinnamiques totaux et activités antioxydantes chez les Apiacées, les Borraginacées et les Lamiacées médicinales," Annales Pharmaceutiques Françaises, vol. 48, no. 2, pp. 103-108, 1990.

[18] B. Chassaing, J. D. Aitken, M. Malleshappa, and M. VijayKumar, "Dextran sulfate sodium (DSS)-induced colitis in mice," Current Protocols in Immunology, vol. 104, unit 15-25, 2014.

[19] M. P. Utrilla, M. J. Peinado, R. Ruiz et al., "Pea (Pisum sativum L.) seed albumin extracts show anti-inflammatory effect in the DSS model of mouse colitis," Molecular Nutrition and Food Research, vol. 59, no. 4, pp. 807-819, 2015.

[20] D. Camuesco, M. Comalada, M. E. Rodríguez-Cabezas et al., "The intestinal anti-inflammatory effect of quercitrin is associated with an inhibition in iNOS expression," British Journal of Pharmacology, vol. 143, no. 7, pp. 908-918, 2004.

[21] J. Sedlak and R. H. Lindsay, "Estimation of total, proteinbound, and nonprotein sulfhydryl groups in tissue with Ellman's reagent," Analytical Biochemistry, vol. 25, no. 1, pp. 192-205, 1968.

[22] Z.-Y. Jiang, J. V. Hunt, and S. P. Wolff, "Ferrous ion oxidation in the presence of xylenol orange for detection of lipid hydroperoxide in low density lipoprotein," Analytical Biochemistry, vol. 202, no. 2, pp. 384-389, 1992.

[23] S. Marklund and G. Marklund, "Involvement of the superoxide anion radical in the autoxidation of pyrogallol and a convenient assay for superoxide dismutase," European Journal of Biochemistry, vol. 47, no. 3, pp. 469-474, 1974.

[24] M. S. Blois, "Antioxidant determinations by the use of a stable free radical," Nature, vol. 181, no. 4617, pp. 1199-1200, 1958.

[25] F.-A. Chen, A.-B. Wu, and C.-Y. Chen, "The influence of different treatments on the free radical scavenging activity of burdock and variations of its active components," Food Chemistry, vol. 86, no. 4, pp. 479-484, 2004.

[26] P. P. Bradley, D. A. Priebat, R. D. Christensen, and G. Rothstein, "Measurement of cutaneous inflammation: estimation of neutrophil content with an enzyme marker," The Journal of Investigative Dermatology, vol. 78, no. 3, pp. 206-209, 1982.

[27] L. M. De Young, J. B. Kheifets, S. J. Ballaron, and J. M. Young, "Edema and cell infiltration in the phorbol ester-treated mouse ear are temporally separate and can be differentially modulated by pharmacologic agents," Agents and Actions, vol. 26, no. 3-4, pp. 335-341, 1989.

[28] M. B. Grisham, G. G. Johnson, and J. R. Lancaster Jr., "Quantitation of nitrate and nitrite in extracellular fluids," Methods in Enzymology, vol. 268, pp. 237-246, 1996.

[29] H. Zhang, H. Wu, L. Liu, H. Li, D. Q. Shih, and X. Zhang, "1,25dihydroxyvitamin $\mathrm{D}_{3}$ regulates the development of chronic colitis by modulating both T helper (Th)1 and Th17 activation," APMIS, vol. 123, no. 6, pp. 490-501, 2015.

[30] L. Kruidenier, I. Kuiper, C. B. H. W. Lamers, and H. W. Verspaget, "Intestinal oxidative damage in inflammatory bowel disease: semi-quantification, localization, and association with mucosal antioxidants," The Journal of Pathology, vol. 201, no. 1, pp. 28-36, 2003.

[31] Y. Yeom and Y. Kim, "The Sasa quelpaertensis leaf extract inhibits the dextran sulfate sodium-induced mouse colitis through modulation of antioxidant enzyme expression," Journal of Cancer Prevention, vol. 20, no. 2, pp. 136-146, 2015.

[32] J. R. Santin, Marivanelemos, L. C. Klein-Júnior et al., "Gastro protective and anti-Helicobacter pylori effects of a flavonoid rich fraction obtained from Achyrocline satureoides (LAM) D.C," International Journal of Pharmacy and Pharmaceutical Sciences, vol. 6, no. 7, pp. 417-422, 2014. 
[33] N. Goyal, A. Rana, A. Ahlawat, K. R. V. Bijjem, and P. Kumar, "Animal models of inflammatory bowel disease: a review," Inflammopharmacology, vol. 22, no. 4, pp. 219-233, 2014.

[34] G. K. Zorzi, F. Caregnato, J. C. Moreira, H. F. Teixeira, and E. L. Carvalho, "Antioxidant effect of nanoemulsions containing extract of Achyrocline satureioides (Lam) D.C.-asteraceae," AAPS PharmSciTech, vol. 17, no. 4, pp. 844-850, 2016.

[35] C. Casero, F. Machín, S. Méndez-Álvarez et al., "Structure and antimicrobial activity of phloroglucinol derivatives from Achyrocline satureioides," Journal of Natural Products, vol. 78, no. 1, pp. 93-102, 2015.

[36] M. J. González, V. G. Beoletto, A. M. Agnese, M. C. Audisio, and J. M. Marioli, "Purification of substances from achyrocline satureioides with inhibitory activity against paenibacillus larvae, the causal agent of american foulbrood in Honeybees' larvae," Applied Biochemistry and Biotechnology, vol. 175, no. 7, pp. 33493359, 2015.

[37] J. Bidone, D. F. Argenta, J. Kratz et al., "Antiherpes activity and skin/mucosa distribution of flavonoids from achyrocline satureioides extract incorporated into topical nanoemulsions," BioMed Research International, vol. 2015, Article ID 238010, 7 pages, 2015.

[38] Y. Nishitani, K. Yamamoto, M. Yoshida et al., "Intestinal antiinflammatory activity of luteolin: role of the aglycone in NF$\kappa \mathrm{B}$ inactivation in macrophages co-cultured with intestinal epithelial cells," BioFactors, vol. 39, no. 5, pp. 522-533, 2013.

[39] D. Dodda, R. Chhajed, J. Mishra, and M. Padhy, "Targeting oxidative stress attenuates trinitrobenzene sulphonic acid induced inflammatory bowel disease like symptoms in rats: role of quercetin," Indian Journal of Pharmacology, vol. 46, no. 3, pp. 286-291, 2014.

[40] H. Yu, L.-H. Wu, Z.-L. Xu, D. Dong, and S.-A. He, "Protective effect of anthocyanins extract from blueberry on TNBSinduced IBD model of mice," Evidence-Based Complementary and Alternative Medicine, vol. 2011, Article ID 525462, 8 pages, 2011.

[41] S. P. L. Travis, "Which 5-ASA?” Gut, vol. 51, no. 4, pp. 548-549, 2002.

[42] V. G. Pillarisetty, A. B. Shah, G. Miller, J. I. Bleier, and R. P. DeMatteo, "Liver dendritic cells are less immunogenic than spleen dendritic cells because of differences in subtype composition," The Journal of Immunology, vol. 172, no. 2, pp. 1009-1017, 2004.

[43] S. Cornick, A. Tawiah, and K. Chadee, "Roles and regulation of the mucus barrier in the gut," Tissue Barriers, vol. 3, no. 1-2, Article ID e982426, 2015.

[44] Y. Merga, B. J. Campbell, and J. M. Rhodes, "Mucosal barrier, bacteria and inflammatory bowel disease: possibilities for therapy," Digestive Diseases, vol. 32, no. 4, pp. 475-483, 2014.

[45] D. R. Clayburgh, L. Shen, and J. R. Turner, "A porous defense: the leaky epithelial barrier in intestinal disease," Laboratory Investigation, vol. 84, no. 3, pp. 282-291, 2004.

[46] A. Bhattacharyya, R. Chattopadhyay, S. Mitra, and S. E. Crowe, "Oxidative stress: an essential factor in the pathogenesis of gastrointestinal mucosal diseases," Physiological Reviews, vol. 94, no. 2, pp. 329-354, 2014.

[47] Y. J. Kim, E.-H. Kim, and K. B. Hahm, "Oxidative stress in inflammation-based gastrointestinal tract diseases: challenges and opportunities," Journal of Gastroenterology and Hepatology, vol. 27, no. 6, pp. 1004-1010, 2012.

[48] J. Zhao, T. Hong, M. Dong, Y. Meng, and J. Mu, "Protective effect of myricetin in dextran sulphate sodium-induced murine ulcerative colitis," Molecular Medicine Reports, vol. 7, no. 2, pp. 565-570, 2013.

[49] J. Pedersen, M. Coskun, C. Soendergaard, M. Salem, and O. H. Nielsen, "Inflammatory pathways of importance for management of inflammatory bowel disease," World Journal of Gastroenterology, vol. 20, no. 1, pp. 64-77, 2014.

[50] C. Banks, A. Bateman, R. Payne, P. Johnson, and N. Sheron, "Chemokine expression in IBD. Mucosal chemokine expression is unselectively increased in both ulcerative colitis and Crohn's disease," The Journal of Pathology, vol. 199, no. 1, pp. 28-35, 2003.

[51] R. Sreedhar, S. Arumugam, V. Karuppagounder et al., "Jumihaidokuto effectively inhibits colon inflammation and apoptosis in mice with acute colitis," International Immunopharmacology, vol. 29, no. 2, pp. 957-963, 2015.

[52] L. A. Dieleman, M. J. H. J. Palmen, H. Akol et al., "Chronic experimental colitis induced by dextran sulphate sodium (DSS) is characterized by Th1 and Th2 cytokines," Clinical and Experimental Immunology, vol. 114, no. 3, pp. 385-391, 1998.

[53] K. V. Barros, R. A. N. Xavier, G. G. Abreu et al., "Soybean and fish oil mixture increases IL-10, protects against DNA damage and decreases colonic inflammation in rats with dextran sulfate sodium (DSS) colitis," Lipids in Health and Disease, vol. 9, article 68, 2010.

[54] G. Paul, V. Khare, and C. Gasche, "Inflamed gut mucosa: downstream of interleukin-10," European Journal of Clinical Investigation, vol. 42, no. 1, pp. 95-109, 2012.

[55] J. O. Lindsay, A. Sandison, P. Cohen, F. M. Brennan, and H. J. F. Hodgson, "IL-10 gene therapy is therapeutic for dextran sodium sulfate-induced murine colitis," Digestive Diseases and Sciences, vol. 49, no. 7-8, pp. 1327-1334, 2004.

[56] H. Groux, A. O'Garra, M. Bigler et al., "A CD4 ${ }^{+}$T-cell subset inhibits antigen-specific T-cell responses and prevents colitis," Nature, vol. 389, no. 6652, pp. 737-742, 1997. 


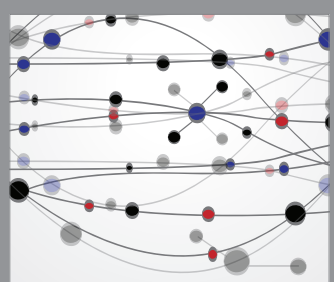

The Scientific World Journal
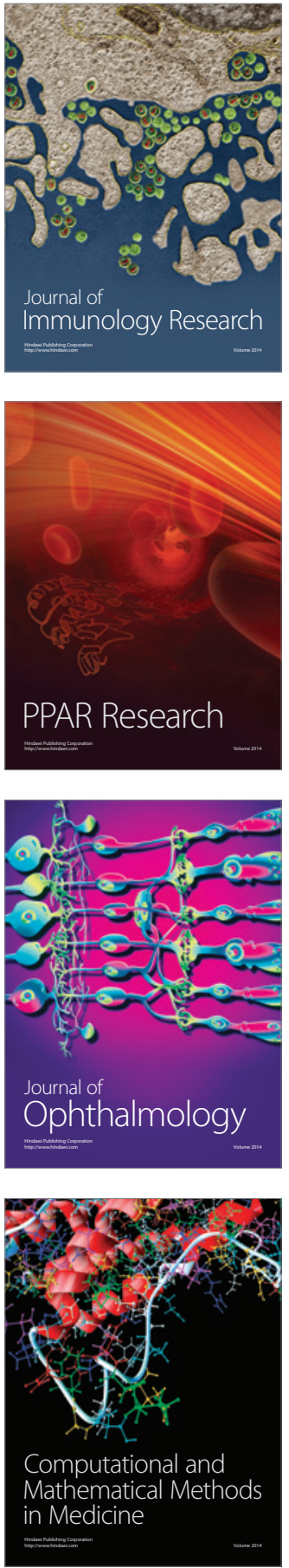

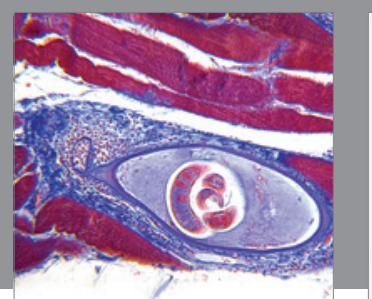

Gastroenterology Research and Practice

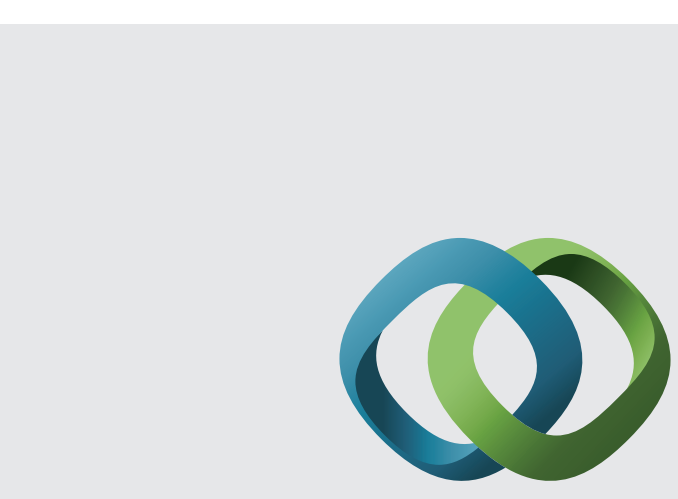

\section{Hindawi}

Submit your manuscripts at

http://www.hindawi.com
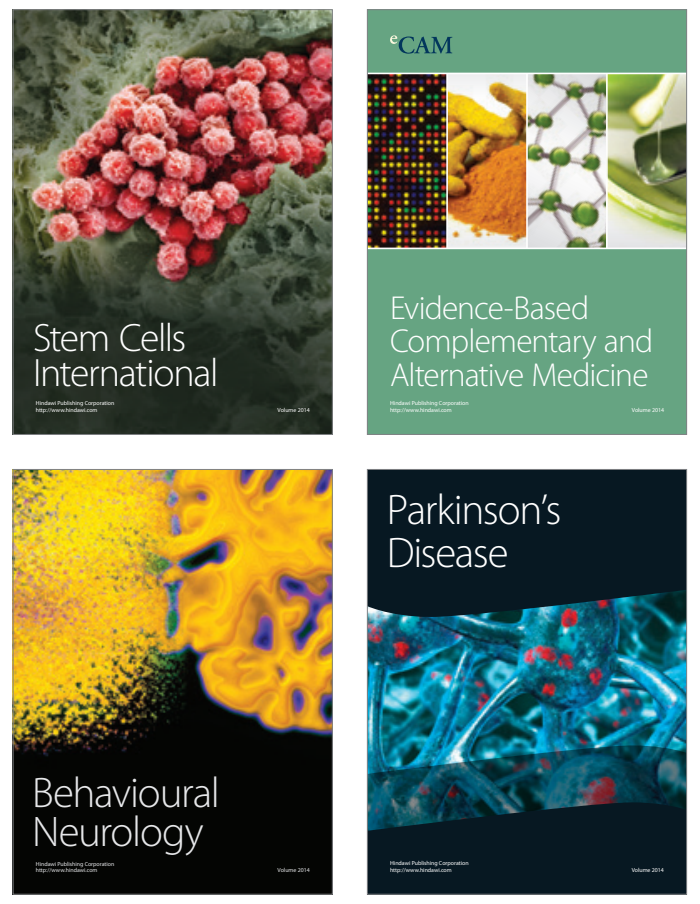
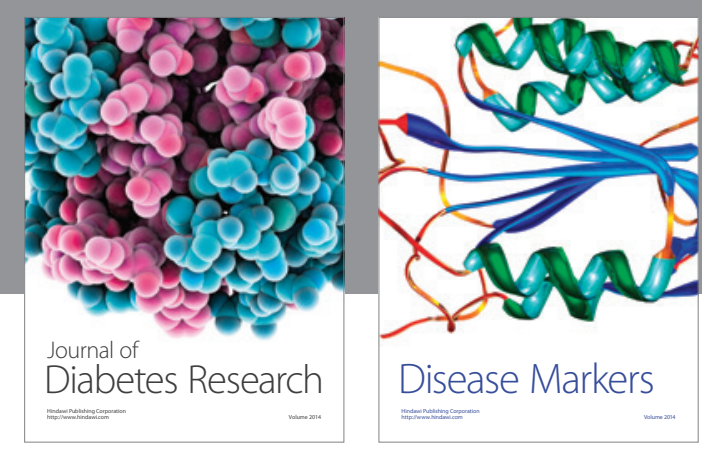

Disease Markers
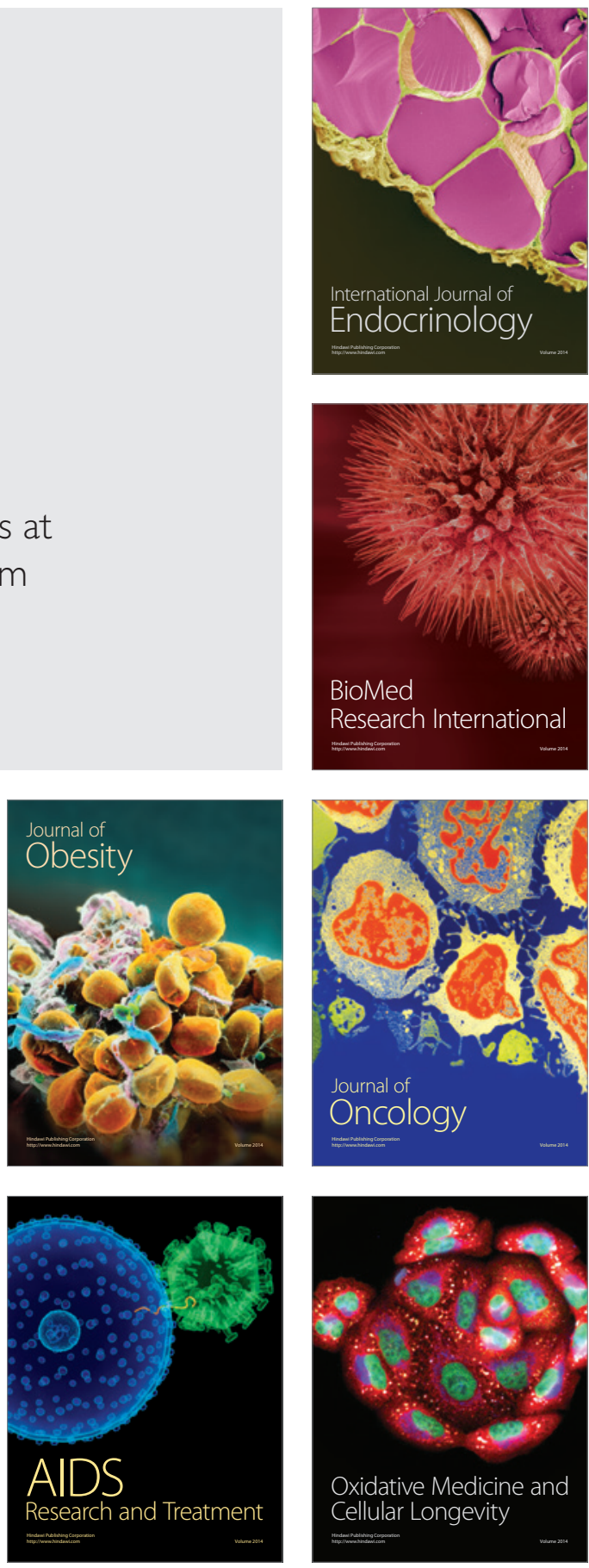